Swiss Institute of Architectural and Archaeological Research on Ancient Egypt, Cairo

\title{
Report on the
}

\section{Ninth Season of the Joint Swiss-Egyptian Mission}

\section{in Syene / Old Aswan (2008/2009)}

\author{
by \\ Cornelius von Pilgrim and Wolfgang Müller
}

in cooperation with Mohamed el-Bialy, Mohi ed-Din Mustafa and Adel Kelany

The ninth season of the joint archaeological project of the Swiss Institute of Architectural and Archaeological Research Cairo and the Supreme Council of Antiquities Aswan (SCA) in Syene/Old Aswan took place between October $11^{\text {th }}, 2008$ and May $5^{\text {th }}, 2009^{1}$.

This season's work focused on rescue excavation in four major construction sites (cf. Area 45, 46, 49 and 52 in Fig. 1). All of them contributed considerably to a growing understanding of the town development during the long history of Aswan².

\footnotetext{
${ }^{1}$ We are grateful to the Supreme Council of Antiquities and the members of the Permanent Committee, and in particular to the General Secretary, ZAHI HAWASS, for granting permission to undertake the Joint Mission in Aswan. We appreciate very much the fruitful cooperation with our colleagues of the Aswan Inspectorate in this joint mission. The mission was directed by CORNELIUS VON PILGRIM and MOHAMED EL-BIALY. The fieldwork was directed by WOLFGANG MÜLLER. Further members were the archaeologists E. CruZ-Uribe, A. Gascoigne, M. FinK, I. Forstner-Müller, R. Fuchs, M. HePA, K. Hofmann, R. Huber, A. Kelany, S. Ladstätter, P. Moser, G. PARrer, L. Rembart, L. Werlen, the numismatist H.C. NOESKE, the fotografer A. KRAUSE, the geomorphologist M. DE DAPPER, the palaeobotanists U. THANHEISER and S. WIESINGER, the palaeozoologists L. BERTINI and J. SiGL, the anthropologists J. NOVACEK, K. SCHEELEN and M. SCHULTZ and the conservator E. PEINTNER. The assigned inspectors were Hussein Mahsoub, Mahmoud Abdellah, Usama Amer and Hany Salah Mahmoud Mansour. ${ }^{2}$ For previous work of the mission see C. VON PILGRIM et al., 'The Town of Syene. Preliminary Report on the $1^{\text {st }}$ and $2^{\text {nd }}$ Season in Aswan' in: MDAIK 60 (2004), 119-148 (quoted hereafter as $1^{\text {st }}$ and $2^{\text {nd }}$ Season). C.
} 
A significant discovery was a domestic building of the Middle Kingdom near the southern end of the modern market street (Area 45). The location of the site, north of the walled town of the Late Period and beyond, indicates either a shift of the settlement after the New Kingdom or a much larger extension of the town in Pharaonic times. The hitherto northernmost segment of the Late Period city wall was uncovered in another construction site further south. (Area 46). It was provided with a temporarily used gateway. The wall, however, was overbuilt already in the early Ptolemaic Period. Thus it remains unclear whether the fortification was then restricted to the town centre or whether the extending town had been enclosed with a new city wall.

Tombs of the Roman and Byzantine Period were found in several areas attesting extensive and densely occupied cemeteries north of the Roman town (Areas 45, 49 and 51). All of them were covered with a thick layer of waste in the Mamluk Period before the domestic quarters spread to the north. Rural dwellings of the northern suburbs of the Mamluk town were met in Area 49. They were abandoned for a certain period of time and were covered with wind-blown sand before the area was reoccupied with industrial installations. In the Mamluk Period the town has not only extended significantly further north but has also shifted towards the Nile following the siltation of the riverbank. In the centre of the town a certain segment of a massive river embankment wall was uncovered in the area of the German Missions Hospital (Area 52). Apparently it was connected here with a waterwheel lifting water into basins on top of the wall.

Beside the current field work the restoration and documentation of small finds and coins were continued as well as palaeobotanical, anthropological and zoo-archaeological studies. The pottery studies concentrated on Ptolemaic and Roman pottery found in previous seasons in Areas 13 and 15 as well as on a first evaluation of the Middle Kingdom pottery from Area $45^{3}$.

1) Area 41: The fortification wall between Old Aswan and Konosso (Fig.2)

In the southern outskirts of Aswan ongoing construction works of the City Council along the road to Shellal continued to menace the unique fortification wall between Old Aswan and Konosso ${ }^{4}$. The most endangered segment of the wall lies between the entry road and the exit road leading to the harbour of Philae where the area along the road will be grassed and used as exhibition ground for modern sculptures. Therefore, the mission continued to clean a $200 \mathrm{~m}$ long part of the wall,

VON PILGRIM et al., 'The Town of Syene. Report on the $3^{\text {rd }}$ and $4^{\text {th }}$ Season in: Aswan' in MDAIK 62 (2006), 215-277 (quoted hereafter as $3^{\text {rd }}$ and $4^{\text {th }}$ Season) and C. von PILGRIM et al., 'The Town of Syene. Report on the $5^{\text {th }}$ and $6^{\text {th }}$ Season in Aswan' in: MDAIK 64 (2008 in press) (quoted hereafter as $5^{\text {th }}$ and $6^{\text {th }}$ Season).

${ }^{3}$ The pre-Roman pottery is studied by SABINE LADSTÄTTER. and LAURA REMBART, the Middle Kingdom pottery is studied by IRENE FORSTNER-MÜLLER.

${ }^{4}$ Cf. H. JARITZ, in MDAIK 43, 1987, p. 67-74 and H. JARITZ, in: MDAIK 49, 1993, p. 107-118. 
which is located immediately in the back of the planed exhibition ground ${ }^{5}$. After the removal of all dumps covering the wall both construction phases attested in sondages during the previous season became clearly visible. Consolidation measures including a drainage ditch and a restoration of the partly destroyed outer face of the wall shall be executed in the forthcoming season.

(C.von Pilgrim)

2) Area 44: Stone architecture of the Mamluk period

Investigations in Area 44 were of limited time and scale due to the small size of the area and the derelict neighbouring houses ${ }^{6}$. A massive stonewall running north-south was detected in a small trench in the centre of the area. The wall was made of sandstone and very hard lime-mortar. The eastern face of the wall was whitewashed while the western face was kept raw. Hence the structure presumably was the western wall of a cellar.

3) Area 45: Mamluk city quarter, Late Roman burials and a Middle Kingdom house

The Area was located in a part of modern where numerous excavations had taken place previously $^{7}$. Its immediate western neighbour, Area $24,{ }^{8}$ had produced an east west street with adjoining shops dating to the Mamluk period, a large dump with settlement debris and industrial waste from the Early-Islamic period and elaborate chamber tombs with multiple burials dating to the very end of the Roman era. A similar sequence was detected in Area 21. ${ }^{9}$ While in Area 24 the Mamluk phase could be studied in detail, the layer of Roman burials was only touched in small trenches. The uninterrupted sequence from the Ottoman down to the Early Islamic period in Area 37 did obviously not continue further to the east where in pre-Mamluk times waste produced by the workshops of the Soukh was deposited in large quantities. In Area 25 to the

\footnotetext{
${ }^{5}$ The Mission is utmost grateful to ZAHI HAWASs for a prompt permission to carry on this urgent work on a larger scale. The work lasted from December 1st to December 13th 2008, January 11th until January 19th 2009 and finally from March 9th until March 14th 2009.

${ }^{6}$ The area is situated in Shona to the south of the Sh. Mohamed Khaled near the Orchida hotel. The excavation was conducted by MUSTAFA HASSAN KHALIL with a team of Inspectors from the SCA Aswan. The excavation lasted from May $1^{\text {st }}$ until June $1^{\text {st }} 2008$.

${ }^{7}$ 56, Sh. Abbas Farid.

${ }^{8}$ F. MAHMUD EL-AMin in $5^{\text {th }}$ and $6^{\text {th }}$ Season, 340-343.

${ }^{9}$ C. v. PILGRIM in $5^{\text {th }}$ and $6^{\text {th }}$ Season, 340.
} 
south east Early Roman burials and a massive layer of Middle Kingdom settlement debris were detected. $^{10}$

Area 45, western sector ${ }^{11}$

The excavated area covered approximately 122sqm. The east-west road detected in Area 24 continued into the area for $7 \mathrm{~m}$ and was then destroyed by a modern sanitary pit. Like in Area 24, two shops with small porches were situated to the south of the road. Together with Area 24 five shops of similar size (one room with an east-west extension of 2.3-2.6m) were investigated. As only a very small part of the buildings to the north of the street was within the excavated area little can be said about their layout. They did not resemble the shop area to the south. The Mamluk buildings did not show a lot of phases. They were erected on top of the massive layer of waste and debris also found in Area 24. The material from this layer has yet to be studied in detail but can be dated to the Ayyubid to Early Islamic periods.

The debris covered a cemetery (fig. 3). The tombs consisted of a subterranean vaulted burial chamber and elaborate superstructures consisting of a platform made of fired or unfired mudbricks, an entrance-shaft to the west and a smaller platform, partly with a carefully crafted and plastered surface, mostly to the west of the tomb. The tombs were densely clustered to the west of the area and thinning out towards the east. Most tombs had carefully crafted platforms attached to its west. A large platform constructed of sandstone slabs and coated in white lime-plaster was connected to a large rectangular superstructure to its east. Most of these tombs contained multiple burials. Three stelae were reused in these superstructures (fig. 4). ${ }^{12}$ A most peculiar discovery was a cremation burial that had taken place within one of the rectangular superstructures. Cremation, uncommon in Egypt, even during the Early Roman period, was not expected at all in a cemetery of the Coptic period.

In spite of the promising fact that Pharaonic pottery and dolorite hammers were found in several large pits at the eastern limit of the area, a leaking sewer and other problems caused an unscheduled stop of the excavation after the tombs had been opened and the burials retrieved.

Area 45, eastern sector ${ }^{13}$

\footnotetext{
${ }^{10}$ F. MAHMUd EL-Amin in $5^{\text {th }}$ and $6^{\text {th }}$ Season, 343-246.

11 The excavation took place from May $1^{\text {st }}$ to August $29^{\text {th }} 2008$ and was conducted by MUSTAFA HASSAN KHALIL and FAHMI MAHMUD EL-AMIN with a team of inspectors from the SCA Aswan.

12 The stelae show Greek inscriptions and were preliminarily dated to the Late Roman period by JITSE H.F. DIJKSTRA whom I thank for this information.

${ }^{13}$ The excavation took place from October $10^{\text {th }}$ to December $10^{\text {th }} 2008$ and was conducted by a team of the Swiss Institute for Architectural and Archaeological Research on Ancient Egypt in Cairo.
} 
The significantly smaller eastern sector covered an area of $45 \mathrm{sqm}$. Due to security reasons only approximately 20sqm were excavated archaeologically. Two sanitary pits with a round crosssection destroyed most of the later layers. Their side walls were made of reused sandstone blocks. They were roofed with a vault made of fired bricks There were no traces of Mamluk architecture. The massive layer of settlement debris and waste consisting to a high degree of burnt material, slag and glass, was covered by modern debris. The black layer consisted of numerous thin ashy streaks. It inclined and thinned out towards the east (fig. 5).

\section{The Late Roman cemetery}

Most of the latest cemetery phase was at least partly disturbed. None of the tombs of this stratum, so well preserved in the western sector, were found intact in the east. A densely clustered group of tombs at the western limit of the excavation was mostly covered by the western section (figs. 6-7). Tomb 4 was destroyed by one of the sanitary pits, another chamber tomb was documented in the southern section but not opened. Like in the western sector all tombs of this phase were oriented east-west.

No entrance shafts were encountered within the investigated area. Tombs 1,2 and 10 were of different date. Tomb 1 was built on top of Tomb 2 that was slightly later than Tomb 10. Tomb 1 was covered by a vault of fired bricks that later collapsed. The burial chamber measured $0.50 \mathrm{x}$ $1.20(+x) \mathrm{m}$, and was approximately $0.5 \mathrm{~m}$ high. Tomb 1 was the only tomb where fired bricks were used.

The burial chambers of Tombs 2 and 10 were more spacious. They were 1.20 wide and had a reconstructed height of $0.8 \mathrm{~m}$ (Tomb 2) respectively more than $1 \mathrm{~m}$ (Tomb 10). The apex of the vaults was destroyed by the dumping activity during the Early Islamic period (fig. 5). Tomb 10 was carefully constructed on top of a shallow sand bed filled with pure whitish sand.

While Tomb 1 contained a single burial, all other tombs of this phase were used for multiple burials. Tomb 2 contained 12, Tomb 10 14, Tomb 4 at least 4 individuals. All skeletons were interred in a supine position with the head in the west. Due to the orientation and location of the tombs within the area, only the lower extremities of the bodies could be excavated. Skulls were only found in Tomb 4 and Tomb 10 (from a disturbed burial). Most individuals were adult or juvenile. $^{14}$

The next earlier phase of the cemetery consisted exclusively of simple pit graves with single burials. The orientation was the same as in the later phase. Again the bodies were buried in a

\footnotetext{
${ }^{14}$ JAN NOWACEK is currently preparing a study on the anthropological material of the cemetery.
} 
supine position with the head in the west. The 8 graves of this phase contained only infantile and juvenile burials. Except a bowl and a necklace of faience beads the burials were, like in the later phase, bare of any grave goods.

The 4 graves dating to the beginning of the cemetery showed a completely different orientation and construction (fig. 8). The burials were put in deep north-south oriented pit graves in a supine position with the head in the north. The infill of the grave pit contained a high proportion of stones, mostly broken granite and Pharaonic dolorite hammers. The burial at the bottom of the pit was put in a small chamber with an approximately anthropomorphic ground plan, constructed of a single course of mud bricks. Stones, mostly granite slabs covered the chamber.

Due to the lack of grave goods in all phases of the cemetery, absolute dating is difficult. A coin of Constantius II, found in one of the graves of the second phase gives a terminus in the second half of the $4^{\text {th }}$ century AD. The earliest phase of burials has close parallels in Quesna in the Minufiyeh region. ${ }^{15}$ These burials are dated to the Ptolemaic period. ${ }^{16}$ The brick-chambers are covered with mud bricks, probably due to the lack of stone in the Delta. The arms of the interred are crossed over the chest. The arms of the bodies in Area 45 were positioned in a natural way at the sides of the upper body.

The astonishing number of individuals (47) in such a small area gives, especially taken together with the more than 100 skeletons from the western sector of Area 45, an impression of the population of Syene from the Roman Imperial Period until the Islamic conquest.

The peculiar fact that there was no building activity in the Early Islamic and Ayyubid periods merits closer scrutiny. In Area 24 a house was built on top of the cemetery in the Ayyubid period. ${ }^{17}$ As the tombs in Area 45 were much later, probably still used, or the interred still known, when the Islamic conquest took place, the Christian cemetery was respected until it had completely vanished under a cover of waste.

\section{Pharaonic activities}

The layers prior to the cemetery show a completely different character. Several pits, postholes and filling layers with dates ranging from the New Kingdom to the Roman Period were very difficult to interpret due to the small size of the excavated area. These activities did a lot of damage to the older strata.

\footnotetext{
${ }^{15}$ J. RowLAND, 'The Ptolemaic-Roman Cemetery at the Quesna Archaeological Area', in: JEA 94, 2008, 76- 78 fig. 6.

${ }^{16}$ Ibid,. 91.

${ }^{17}$ F. MAHMUd EL-Amin in $5^{\text {th }}$ and $6^{\text {th }}$ Season, 343.
} 
Middle Kingdom domestic structures (figs. 9-10)

These strata contained the first domestic architecture of Pharaonic date ever found in modern Aswan. Two rooms of a house were excavated. The building had been constructed in the middle of Dynasty 12 and was occupied well into Dynasty $13^{18}$.

\section{Earlier building phase}

The original concept consisted of two walls, one running north-south in the northernmost part and the other east-west in the very east of the site. They were organizing the excavated area into four rooms. The walls were set into a sand-dune, accumulated by wind along the river bank. ${ }^{19}$ The walls were at least two bricks wide and significantly wider at the bottom than further up. They were preserved to a height of $1.80 \mathrm{~m}$ and showed traces of heavy erosion and frequent repairs. The dimensions of the (not very compact sandy) mud bricks were with $(0.35-0.40) \times 0.20 \times 0.10 \mathrm{~m}$ considerable.

The existence of two eastern rooms was verified without further investigation. Only 2sqm of the north western room (Room 1) were within the excavated area. Both its eastern and western walls were detected, giving the width of the room as $2 \mathrm{~m}$. The earliest floor in Room 1 rested on a filling layer of sand and granite rubble. The floor was burned and covered with fine ashy layers of charcoal. A multi-phase approximately square (side length $0.6-0.7 \mathrm{~m}$ ) cooking and baking installation was set into the south-eastern corner of the room. The square was bordered by breadmoulds, some of them had been put in the hot embers, other pottery and a grinding stone deposited upside down.

The southern room, probably a courtyard, was significantly larger and served as multi functional cooking and workshop area. In a working area in the southern part of Room 2, bordered by narrow mud-brick walls with frequently changing layout, flint-tools were produced and sharpened among other activities. Three fire-pits were lined up along the northern wall of the room, the most prominent of them bordered by burned mud-bricks in the north eastern corner. Both faces of the east-west wall were significantly damaged by the heat and fire as was the eastern wall of Room 1 with burned niches hollowed out by the fireplaces. The fire pits and working areas in Room 2 were accompanied by partly buried pottery vessels (Beerbottles).

Later building phase and abandonment

\footnotetext{
18 The pottery was preliminarily dated by IRENE FORSTNER-MÜLLER whom I thank for this information.

${ }^{19}$ A similar dune was encountered in Area 37 and interpreted by MORGAN DE DAPPER.
} 
In the later building phase detected in the eastern extension of Area 45, several repairs and minor changes took place in the house.

In Room 1, a wall was constructed in a distance of $0.70 \mathrm{~m}$ from the eastern wall. The wall projected only centimetres into the excavated area, left room for an approximately $0.7 \mathrm{~m}$ wide door that now connected the new subdivisions of former Room 1. The floors of this phase were not as ashy as before. After its abandonment, the Room was filled in with settlement debris containing a high proportion of burned mud-bricks and parts of ovens.

More pronounced changes took place in Room 2. A north-south wall made of mud bricks of very bad quality ran in a distance of little more than $1 \mathrm{~m}$ from the eastern wall of the former room. Due to contemporary ovens arranged along the northern wall of the room the northern end of the new wall could be verified. As the area to the west of the wall was disturbed by later graves and pits, no adjoining east west wall could be found. If such a wall is reconstructed, the corner of a house to the south was reducing the available space available in former Room2. The foundation of the north-south wall was a carefully laid platform made of granite slabs and. It contained a reused pottery offering plate.

\section{Old Kingdom Activities}

Pottery dating to Dynasty 5 and $6^{20}$ was found immediately on top of the sand dune under the Middle Kingdom structures. This material may be connected to the earliest activities detected in Area 37, where a buried vat with perforated bottom was found together with contemporary bread moulds and beer bottles.

\section{Interpretation of the Pharaonic Phases}

The restricted size of the excavated area makes any interpretation of the findings difficult. The most crucial question is, whether the houses in Area 45 are part of a full scale Middle Kingdom settlement on the eastern bank of the Nile or if they constitute only part of a distribution- or workshop centre serving quarrying activities in the area. As settlement layers of the Middle Kingdom had been found in the far north of Aswan, in Areas 18 and 23, ${ }^{21}$ a substantial settlement may be taken into consideration. The settlement history of this part of Aswan did not start before the Middle Kingdom. Further excavations near Area 45 will shed further light on the development of Pharaonic Aswan.

\footnotetext{
${ }^{20}$ I thank DIETRICH RAUE for this assessment.

${ }^{21}$ Von PILGRIM, $5^{\text {th }}$ and $6^{\text {th }}$ Season, 312.
} 


\section{4) Area 46: Ptolemaic domestic structures and the Late Period city wall}

The site ${ }^{22}$, just to the west of Area 36 and one house to the north of Area 43, is situated on very high ground (street level approximately $108 \mathrm{~m}$ asl) due to a granite outcrop with the highest point the north-east of the site(elevation $107.8 \mathrm{~m}$ ). This outcrop is depicted on the map of the Description de l' Egypte ${ }^{23}$ to the east of the temple of Domitian. The overall situation on the site is very similar to Area 36: the modern buildings were erected immediately on top of the granite in the north and on remains of Ptolemaic buildings in the south of the area. Modern foundation trenches damaged all ancient remains.

\section{Modern activities}

A foundation made of granite and sandstone (mostly quarry debris and chips of different sizes) to the very south of the area, the northern wall of a building lying mostly under the modern street and houses, is evidence of the fact that the modern street grid, just as in most other areas investigated by the Joint Mission, does not have a long tradition as material taken from the foundation gives a terminus post quem for its erection in the Late Ottoman Period, probably as late as the early $20^{\text {th }}$ century.

Ptolemaic domestic structures (figs. $11-12$ )

The Ptolemaic building layer consisted of a house built against the sloping hill. Two rooms of the house were detected. The western room (Room 1) was completely preserved (5.12 x 2.90m) while the eastern room (Room 2) was partly and another reconstructed room to the south of the building was completely destroyed by modern foundations.

The house was covering the southern half of the site and had significantly higher floors in its eastern part than in the west. A staircase (1.1m wide) was attached to the northern wall of the building with five stone steps still preserved. The main entrance into the house was from the north-west of Room 1. A later walled up threshold with marks of a hinge in the north remained of the door that led into the building from the west via two steps built into the western wall of the house. Another door led from Room 1 to the room immediately to the south. Room 1 most probably constitutes a courtyard, the staircase built against its southern wall did not belong to the

${ }^{22}$ Sh. Mohamed Mansur Kaiely. The work started in June 2008 and was then conducted by a team of the SCA Aswan under the responsibility OF MUSTAFA HASSAN KHALIL. In October $11^{\text {th }} 2008$ a team of the Swiss Institute took over. The excavation was conducted by MARIOLA HEPA, PATRICK MOSER and WOLFGANG MÜLLER and lasted with interruptions until March $30^{\text {th }} 2009$.

${ }^{23}$ Description I, pl. 31. 
house but rather represents a public staircase, part of a small street. The sloping ground made building-terraces necessary that were connected by staircases.

Room 1 contained a small pen, probably for poultry, in its south eastern part and a battery of two ovens in its north east. The cooking and baking area had been refurbished numerous times. The lower part of a typical cylindrical bread-oven in the north eastern corner occupied most of the available space (diameter: $0.7 \mathrm{~m}$ ). A smaller oven (diameter: $0.30 \mathrm{~m}$ ) to its south was bordered by mud-bricks that were abutting the wall to the east of the battery and touching the wall of the pen to its south. The working area connected to the ovens was marked by an accumulation of ashes and charcoal that spread towards the west and ended at the same distance from the eastern wall as the pen.

The pen consisted of a feeble northern mud-brick wall and a wooden construction as its western limit. The wooden construction was mostly destroyed but traces of a wooden beam, probably the base of a fence, were still in situ. It was filled with organic material, predominantly dung. The square structure measured approximately $1.40 \times 1.40 \mathrm{~m}$ and presumably served as a pen for poultry. The courtyard served, as was typical of such rooms, different purposes. Structures within the courtyard were of a temporary nature. Several older ovens and parts of them are evident both in the north-eastern corner and all over the place. The pen was added to the layout during the later phases of use of the courtyard. In the earlier phases the area immediately to the north of the door into the southern room was paved with sandstone slabs that were abutting the sandstone threshold. An indentation in the floor in the south eastern corner, bordered towards the west by a narrow mud-brick wall, was the last trace of an oven while no such installation could be found in the later cooking area in the north eastern corner. A row of sandstones, probably a small intermediary wall was projecting $1.40 \mathrm{~m}$ from the northern wall of the room, well aligned with two bricks abutting the southern wall, indicates that the courtyard was organized in a more complex way originally.

Room 2 was used as stables during the later phases of its existence. One metre of goat and sheep dung had accumulated in the room. A small sandstone basin found among the dung may have served as drinking trough. The original use of the room was quite different as a small fireplace, set into a casing of mud bricks that were abutting the northern wall of the room, is not necessarily part of stables.

Both rooms are added to the house proper in an agglutinating way, the living quarters were situated further to the south. 
Several coins give a terminus post quem for the erection of the building during the co-regency of Ptolemy VI and VIII. ${ }^{24}$ Most of the coins were found in a small subterranean vaulted chamber under the southern room. These vaults are a common feature of Ptolemaic Syene. ${ }^{25}$ Older structures, several mud-brick walls among them, were encountered in the area. These structures are too fragmented for a proper interpretation. They constitute parts of older domestic structures, dating to the Ptolemaic period. These activities were restricted to the southern part of the site.

The house in Area 46 is contemporary to the major urban phase in the development of Syene, already encountered in Areas 13, 15 and 19. The structures of Area 43 have yet to be dated properly, but, based on the pottery, a Late Ptolemaic date seems feasible.

As the buildings in Area 36 were too severely damaged to be interpreted or even dated, the much better state of preservation of the house in Area 46 made it possible to reassess the conditions in this part of the town in Middle and Late Ptolemaic times. The most peculiar features of the building are its agricultural connotations. Stables or even dens were missing completely in the more urban quarters of the town studied in the areas mentioned above. They are typical for suburban regions. With the granite sloping steeply further to the north, the buildings in Areas 36 and 46 represent the north-eastern fringe of the densely built-up urban zone. Just as is the case today in similar parts of modern Aswan and its surroundings, goats and small animals find food even on the dire granite.

\section{Late Period}

The city wall (figs. 13-14)

In the westernmost part of Area 36 the eastern face of a massive stone-wall had already been excavated in Season 8. The wall was preserved to a height of 1 to $1.5 \mathrm{~m}$. In Area 46 the western face of the wall came to light at first in the northern part of the site, then in the south under the Ptolemaic house. The wall was running in an approximately north southern direction with a concave front. The width of the wall amounts to $4.20 \mathrm{~m}$ it is preserved to a height of $2.2 \mathrm{~m}$. While the outer face of the wall is constructed with well set partly carefully finished blocks, its core consists of an infill of sandstone rubble and granite chips. The wall is attached to the granite to the north and heavily disturbed by the Ptolemaic buildings in its southern course. A massive buttress was attached to the wall in the south, probably in order to stabilize the construction at the top of a steep incline further to the south.

\footnotetext{
${ }^{24}$ The coins have been dated preliminarily by HANS CHRISTOPH NOESKE.

${ }^{25} \mathrm{~W}$. MÜLLER in $5^{\text {th }}$ and $6^{\text {th }}$ Season, 338.
} 
A small gate was covered by Rooms 1 and 2 of the Ptolemaic house. Two small walls were protruding from the northern and southern walls of the gateway. These doorstops indicate that the outer side of the wicket was to the east of the wall. The width of the gateway measured $1.55 \mathrm{~m}$ in the west and $1.15 \mathrm{~m}$ to the east. The remains of a wooden threshold were detected at the inner side of the doorstop, still connected to traces of the northern part of the doorframe. The eastern and western entrances into the gateway had been walled up in antiquity. The closing wall of the gate and the wall as a whole were coated in a thick layer of muna (mud plaster). Either the construction of the planned gateway had already begun when it was decided to block it again, or its function was only of a limited nature, probably to facilitate the transport of building materials into the city. After the layers, mostly of windblown sand and manure with granite and sandstone chips running against the wall had been removed and the whole front of the wall was thus visible, it became evident that the level of the "threshold" of the gate was approximately $1 \mathrm{~m}$ higher than the base of the wall (fig. 15). The granite in the gateway was only partly removed and then filled in with granite rubble to create a smooth incline of the gateway towards the exit. This level coincides with the lower border of the muna therefore defining the level of the contemporary surface to the west of the gate. Level building ground was created by means of terraces already in the Late Period.

The dismantling of the wall brought new information on its construction. The massive stone structure had been adapted to the uneven ground with numerous single granite boulders by erecting first the faces and leaving the ground immediately under the wall completely unchanged (fig. 16). The area between the faces of the wall was filled in with Granite and sandstone rubble. Even discarded wooden beams were integrated in the body of the wall.

\section{Dating and Interpretation of the wall}

Before the wall was partly destroyed and finally overbuilt, a massive filling-in took place to the west and east of the wall. The filling layers consisted mostly of sandstone chips from the dismantling of the wall and settlement debris with a high percentage of manure. Few clear surfaces contemporary with the period of use of the wall were covered by a massive layer of mud-brick debris (some of it burned) and waste. The city wall was put on top of an older compact surface. The material from the infill is still Ptolemaic in date, the material from the debris and immediately on top of the surface inside the city wall was consistent with the findings from stratum J in Area $15 .^{26}$ The material predating the wall has yet to be studied in detail.

\footnotetext{
${ }^{26}$ The pottery has been preliminarily dated by SABINE LADSTÄTTER.
} 
Besides its date, position and constructional details of the wall make an interpretation of the wall as city wall of Late Period Syene very probable. The wall is still visible to the east of the Temple of Isis in Area 1 and in Area 2. A similar wall has been found in Area $15 .^{27}$ The findings in Area 50 anyhow pose some problem because no city wall was found in this excavation in spite of its location to the immediate north of Area 1 in the projected course of the city wall. ${ }^{28}$

\section{Structures predating the wall}

Not only the natural granite surface was left untouched, earlier structures were also left standing upright and became part of the wall. In the part to the south of the gate the corner of a wall made of small granite fragments and chips, later used as foundation for a mud-brick wall became visible after the dismantling of the stone wall (fig. 17). The mud brick wall was only preserved in the southern part, in the area of the corner of the north-south wall with an east-west wall, the mud-bricks had been removed, probably due to the construction of the wicket. The wall was $0.65 \mathrm{~m}$ wide and showed a small rectangular extension to the west, probably the remains of an east-west wall. The part of the wall made of stone was $1.10 \mathrm{~m}$ high, all of it above ground with an east-west wall abutting to it. This mud-brick wall was further to the east destroyed by the foundation of the buttress. An oven was set in the south-eastern corner of the former room to the north of the mud-brick wall. A pit, coated with mud-plaster was situated to the immediate west of the oven. The oven showed the typical cylindrical shape with a diameter of $0.4 \mathrm{~m}$. It was preserved to a height of $0.4 \mathrm{~m}$.

The northern part of the city-wall covered the remains of a house built into a slightly adapted natural niche in the granite. Only a very compact mud-surface and the northern door into the room, with the hinge still in situ to the east of a threshold quarried out of the rock remained of this building.

Scarce as the architectural remains predating the city wall may be, they show that the first detected houses in this rocky area were built against the slope without elaborate terraces. The material connected to these structures has yet to be studied in detail but it does not seem to be of much earlier date than the later wall.

\section{Earlier Pharaonic activity}

\footnotetext{
${ }^{27}$ W. MÜLLER in $5^{\text {th }}$ and $6^{\text {th }}$ Season, 319 -320. Cf. H. JARITZ, M. RoDZIEWICZ, 'Syene - Review of the Urban Remains and its Pottery' in: MDAIK 52, 1996, 235 for the wall to the east of the Temple of Isis. ${ }^{28}$ Cf. infra chapter 'Area 50'.
} 
In a partly enlarged rocky crevice in the south of the area, partly covered by the southern section, pottery dating to the Middle Kingdom was found among sandy deposits and mud-brick debris. The surface of the granite outcrop was thus occupied throughout the history of Aswan.

The rock inscriptions (fig. 18)

Two rock inscriptions on a granite boulder in the north-western corner formed by the city wall and the northern section have been dated to Dynasty 13. The uppermost inscription is better preserved than the lower one. The inscriptions have close parallels in the two inscriptions from Area $16 .{ }^{29}$ As rock inscriptions often mark ancient lines of communication it is conceivable that the wicket was needed at this part of the city wall in order to avoid interrupting a route existing since the Middle Kingdom. Like in Area 16 the inscriptions were retrieved by a specialist provided by the SCA.

The inscriptions have been preliminarily studied by Marcel Maree who has contributed the following remarks:

Of the two inscriptions the upper one is the most readable. It begins with an address to the living, asking that they recite the offering formula for the benefit of a Controller of followers called Snb.ty.fy, his wife Dd.tw-snb, and at least four more people, conceivably their children. Of the latter, the first was an 'nkh n 3t-Hq' ('officer of the ruler's crew'), i.e. a naval officer, but his name and that of an apparent namesake mentioned after him is still a puzzle. Figures of Snb.ty.fy, holding a staff and 'b3-sceptre, and Dd.tw-snb, smelling a lotus, are depicted below the inscription. The others are only represented by their name determinatives. None of the individuals identified is known from other sources.

With the lower inscription, one can only read what is predictable: snippets of an offering formula. The names of the deities invoked are not as yet recognisable, but the name 3bw, 'Elephantine', occurs among their epithets.

Both inscriptions are probably from the first half of the 13th dynasty. Examination in darkness, with a torch, will probably yield further readings. (M. Maree)

\section{Conclusion}

${ }^{29}$ C. v. PILGRIM in $5^{\text {th }}$ and $6^{\text {th }}$ Season, 313-314 fig. 2. 
The findings of Area 46 add significantly to the picture of the development of ancient Aswan. The town limits marked by the Late Period city wall were not able to contain the population of Hellenistic Syene. The dismantlement and subsequent overbuilding of the wall in the Middle to Late Ptolemaic periods goes well with the hypothesis of a significant growth of population in the first half of the $2^{\text {nd }}$ century BC. ${ }^{30}$

5) Areas 47 and 48: Mamluk city quarter

The areas were located in a densely built up quarter of the modern town on top of a steep slope, significantly higher than the Corniche ${ }^{31}$. The findings of Area 29, an illegal digging $30 \mathrm{~m}$ to the east, showed that massive modern and late Mamluk settlement layers were to be expected. Work was extremely difficult due to derelict modern buildings in the immediate neighbourhood. Only the architecture of the latest building phase, Mamluk houses preserved to a height of $2 \mathrm{~m}$, was documented (fig. 19).

6) Area 49: Suburban area of Mamluk Aswan and Late Roman to Early Islamic Christian tombs (fig. 20)

The area was situated $70 \mathrm{~m}$ to the north-west of Area 31 and $60 \mathrm{~m}$ to the south-east of Area $23 .^{32} \mathrm{~A}$ series of open dens and workshops bordered by mud-walls with some evidence of glassproduction dating to the Mamluk period were found under a massive layer of windblown sand. The accumulation of sand indicates a long period of abandonment. Several phases of graves and tombs dated from the Early Islamic to the Late Roman period. The latest tombs were still oriented east-west, the interred obviously Christian. The earliest tombs were sitting immediately on top of the bedrock.

As Adel Kelany is currently preparing an extensive report on his findings in Area 49 suffice it to stress the importance of this site where the northern limit of the Mamluk town and another cemetery from the end of the Roman period were found.

\footnotetext{
${ }^{30}$ W. MÜlLER, 'Urbanism in Graeco-Roman Egypt' in M. BIETAK, E. CzERnY (EDS.), Cities and Urbanism, Vienna 2009, in print.

${ }^{31}$ The neighbouring area are located in Shona to the east of the Police building. The excavation was conducted by MUSTAFA HASSAN KHALIL and a team of inspectors from the SCA Aswan. The work lasted from August $7^{\text {th }}-29^{\text {th }} 2008$.

${ }^{32}$ Sh. Kelany, near former Aga hotel. Excavations in Area 49 were conducted by ADEL KELANY with a team of inspectors of the SCA Aswan. The work lasted from December $16^{\text {th }} 2008$ until May $21^{\text {st }} 2009$.
} 
7) Area 50: Early Islamic and Late Roman domestic structures

Area 50, located just $22 \mathrm{~m}$ to the north of Area 1, covered an area of $82 \mathrm{sqm}^{33}$. The area lies exactly in the projected course of the city wall to the east of the Temple of Isis in an elevated area of the town. In Area 7, 30m to the north-east, a tower of the Islamic city wall was investigated. ${ }^{34}$ It was therefore expected to encounter the Late Period city wall in the new excavation.

First Islamic building phase: Mamluk to Early Islamic domestic structures (figs. 21-22) ${ }^{35}$

During the latest stratum three houses were grouped along an east west and a north south street. The streets are forming a T-junction in the centre of the excavated area. The portions of the houses uncovered were too small to give clear evidence of their complete layout.

The eastern parts of three rooms of the westernmost House 1 were within the excavated area. The north-south extension of the central room was $2.20 \mathrm{~m}$. The room was partly subterranean with two successive floors, the later floor, probably a sandstone pavement, was completely robbed while the earliest floor, a compact clay-floor, was well preserved. During the later phase, the inner walls of the room were white-washed. The lower end of the lime-plaster gave evidence of the level of the later floor. While the northern wall of the room did not show any significant repairs or changes, the southern wall was completely replaced by a new wall with a massive foundation made of reused sandstone-blocks resting on top of the earlier floor. The remains of the earlier southern wall were located slightly further to the south.

Only the central room was subterranean, the floors of the southern and northern rooms were on a higher level. The eastern wall of the northern room was a massive construction of reused sandstone blocks. The earlier mud-brick wall, well aligned to the former eastern front of the house, was destroyed, as was an earlier vault abutting to it. The earlier phase of the room was equipped with a white-washed vault, corresponding with a vaulted door in the eastern wall.

In the southern room two consecutive sandstone pavements were found. The room was severely damaged by later activities.

The north-south road was $2 \mathrm{~m}$, the east-west road approximately $1.30-1.50 \mathrm{~m}$ wide. During the latest phase of the western house, the east-west street was abandoned and a round pit was created. It was coated with sand-stones and fired bricks in its uppermost courses. The pit destroyed the

\footnotetext{
33 12, Sh. el Berba. The excavation started February $17^{\text {th }}$ and ended May $4^{\text {th }} 2009$. The excavation was conducted by WOLFGANG MÜLLER and LUISE WERLEN.

${ }^{34}$ K. C. BRUHN in $1^{\text {st }}$ and $2^{\text {nd }}$ Season, $140-143$.

35 As neither pottery nor coins have been studied yet, all dates given are of a preliminary nature.
} 
southern wall of the house to the north of the street (House 3). The pit was constructed like a well but not deep enough to reach the water table. Similar pits or shafts were found in several parts of Aswan. ${ }^{36}$ Their function is enigmatic for the time being.

The ground-plan of House 3 remained unchanged throughout the building phase. Only its western wall was replaced with a sand-stone construction during the end of the phase. This repair was contemporary with the construction of the stone-wall to the east of the southern room of House 1 and was due to the very bad quality of mud-brick initially used for Houses 3 and $4 .{ }^{37}$ In the original layout the main entrance into the house was from the east-west road via a door with a sandstone-threshold and a doorframe made in its lower portion of sandstone. The door led into an elongated rectangular room $(1.20 \times 2.50 \mathrm{~m})$ with a staircase in the east. Three stone steps of the staircase were still preserved. The room to the south of the house was damaged by a modern foundation. Traces of a mud-brick vault were still attached to the northern wall of the room. The stone- and wood-reinforcements, attached to the faces of walls, doorways and corners were again due to the bad quality of the building material.

House 2 was still inhabited during the later part of the first Islamic building phase in spite of the fact that the southern room was destroyed. The western wall of the northern room was repaired in a haphazard way and the door into the house was walled up.

The original layout of the house was very similar to House 3 . The main entrance was from the north-south street via a door in the western wall of the southern room. The door showed several repairs. Its original construction was well preserved: a wooden threshold was still connected to the lower parts of a wooden doorframe. From the elongated rectangular (approximately 1 x 4m) corridor to the east of the door a staircase led up to the upper floors in the east and a door, equipped with a sand-stone threshold and a wooden hinge in the east, led into the northern room. Two successive clay-floors were detected in both rooms.

Second Islamic building phase

At the beginning of Islamic activities in Area 50 only the western part of the site was built up. The building occupied exactly the same location as House 1. As the excavated area had to be reduced due to security reasons, only the central part of the house was investigated in some detail. A massive 3m wide platform was bordered by mud-brick walls. The construction constituted the

\footnotetext{
${ }^{36}$ In Area $13 b$ and in Area 1.

${ }^{37}$ Cf. K. C. BRUHN in $1^{\text {st }}$ and $2^{\text {nd }}$ Season, 133 for similar bricks encountered in Area 1 during Phase I (post $7^{\text {th }}$ century AD).
} 
foundation of a heavy structure, probably a high building or part of a building. No contemporaneous layers were detected.

Late Roman building phase (fig. 23)

As the excavated area had to be reduced again, little can be said about the general layout of this phase. The structures were covered by more than $2 \mathrm{~m}$ of filling layers. These layers mostly consisted of windblown predominantly ashy layers alternating with extensive layers of settlement debris. The north-south street already existed during the Late Roman period. It was 2.5 wide. In the western part of the trench the north-eastern corner of a house with a narrow wall abutting to it are the only structures to the west of the north-south street within the excavated area. The eastern face of the house was excavated down to a depth of $2 \mathrm{~m}$ without reaching its base. The small wall to the north of the corner was closing up a former door that showed several phases of repair.

A little bit more was excavated of the buildings to the east of the road. Numerous repairs and changes in the layout were difficult to follow in the small area. The original layout comprised a north-south wall, probably with a door to its north and a corner of two mud-brick walls to its east. These structures were later connected by a east-west wall, finally a narrow east-west wall was added $1 \mathrm{~m}$ to the south of the old corner, connected to the western wall of the building. A LateRoman amphora was integrated into this narrow wall in a peculiar way (fig. 24). Finally the door was walled up with a mud-brick construction and a narrow east west mud-brick wall was crossing the street and abutting both houses thus blocking any traffic on the road.

\section{Conclusion}

The fact that, even in a depth of $7 \mathrm{~m}$ below street level no city wall was found in Area 50 poses a problem for the interpretation of the findings in Area 46. If the wall ever existed at the site, it had been completely removed before the Late Roman period. The orientation of the Roman shrine and the street to the north of it differs significantly from all other streets encountered in this region. ${ }^{38}$ It runs in an approximate right angle to the wall to the east of the Temple of Isis. Based on the hypothesis that the state of preservation of the wall in Areas 1 and 2 is due to a reuse of the wall as temenos-wall in the Ptolemaic and Roman periods, it is conceivable that the orientation of the Roman Shrine is due to the northern part of this wall protecting the temple precinct. The north eastern corner of this precinct could then be situated just to the south of Area 50. Hence there

${ }^{38}$ A. KeLANY, K. C. BRUHN in $1^{\text {st }}$ and $2^{\text {nd }}$ Season, 136-138. 
would have existed no reason to preserve a wall that was destroyed throughout the city in the Ptolemaic period.

The uncovered domestic structures belong to the same city quarter as the houses to the north of the temple of Isis, dating to the Late Roman - Early Islamic periods. ${ }^{39}$ The more recent results of the excavations undertaken by the Swiss-Egyptian Mission to the south of the temple also give precious data for comparison. ${ }^{40}$

(W. Müller)

8) Area 51: A Roman rock tomb (Fig. 25)

On March 17th the mission was informed about an illicit digging in an abandoned private house in Sh. Qudar no 36. A brief examination on the same day disclosed that a deep shaft dug in the house has cut a rock tomb. In agreement with the house owner a brief investigation of the site was then carried out in order to determine the character and the date of the tomb ${ }^{41}$.

Below a $1.30 \mathrm{~m}$ thick layer of modern debris beneath the pavement of the house the shaft (c.80 x c.120 cm) had been cut into the virgin bedrock. About $2.50 \mathrm{~m}$ below the top of the bedrock a cave-like chamber filled with loamy sand is visible in the northern side of the shaft. The bottom of the shaft is about $1 \mathrm{~m}$ deeper than the floor level of the chamber. At the bottom the robber's shaft turned to the south and continued in a slope for another four meters through the virgin bedrock.

The chamber in the northern section of the shaft was filled up with pure wind-blown loamy sand with zones of rubble including fragments of mud-bricks, stone flakes and few pottery sherds. Sequences of thin loamy horizons indicate the infiltration of rainwater in ancient times. The walls and the ceiling of the chamber had been left in a very rough condition. Scattered pieces of granite in the filling were apparently fallen from the ceiling. The chamber has a width of about $1.40 \mathrm{~m}$ and a height of about $1.20 \mathrm{~m}$. The southern limit of the chamber was destroyed by the robber's shaft, whereas the northern end was not met, as it was not possible to extend the excavation further north than 1 meter. However, it might be suggested that the chamber continues further north leading into a central chamber and that it is just a side chamber of a multi-chambered rock tomb. This assumption would help to explain the presence of a broken ceramic vessel at the

\footnotetext{
${ }^{39}$ Personal communication by AdEL KeLANY. The initial excavations were conducted by M. EL-HETTA in 1961 ( $c f$. a short notice by J. LECLANT in Or 31, 1962, 203).

${ }^{40} \mathrm{~K}$. BRUHN in $1^{\text {st }}$ and $2^{\text {nd }}$ Season, $127-134$ and idem in $3^{\text {rd }}$ and $4^{\text {th }}$ Season, 238-251.

${ }^{41}$ The work, executed by C. VON PILGRIM, took place March 21th and March 26 ${ }^{\text {th }}, 2009$.
} 
eastern wall of the chamber on a higher level on top of the lower part of the tomb filling. It might belong to a secondary burial in the unexcavated northern extension of the chamber.

The bottom of the chamber had been executed only in a very rough way as well. On the floor level a skeleton of a simple burial was uncovered beside the eastern wall of the chamber. It was cut by the robber's shaft in the middle of the chest leaving only the chest's upper part and the skull in situ. No grave goods have been found beside the burial. Some scattered human bones (no skulls) to the west of the burial let assume that older burials had been moved aside when it was put into the tomb. Beside one of the scattered bones 15 fayence beads were discovered. They might have been part of a bracelet.

According to the pottery sherds in the filling of the tomb the burial can be dated to the early Roman Period. In addition to another tomb discovered further south by an illicit digging in 1997 the tomb gives a further evidence for a necropolis of rock tombs to the northeast of the GraecoRoman town of Syene.

(C.von Pilgrim)

9) Area 52: Medieval river embankment (figs. 26-27)

In February 2008 a series of drillings was conducted by Morgan de Dapper in the area of the German Hospital in order to look for the pre modern river bank of the Nile ${ }^{42}$. All the drilling cores except those taken at the eastern limit of Area 52 produced a sequence of sterile river sediment. The sediment was similar to the situation in Area 27, situated further to the west and in the course of the ancient river. In the eastern part of Area 52 a layer of debris was detected under the uppermost alluvial layers. This layer was rising towards the east. It was clear from these results that the river bank was to be expected in the easternmost part of Area 52.

After removing the modern building debris, connected to the construction of the Hospital in the early $20^{\text {th }}$ century, an extensive layer of whitish compact river sediment came to light in the western part of the site. Next to the eastern limit of the foundation pit the only architectural structure, a north-south wall with a pronounced corner at its northern end was detected. The northern end of the wall was damaged in its upper portion by a modern sewer. The lower part of the wall is projecting $1 \mathrm{~m}$ to the west. The $10.7 \mathrm{~m}$ long portion of the wall was made of sandstone and preserved to a height of $6.1 \mathrm{~m}$. The construction of the southern and northern part was

\footnotetext{
${ }^{42}$ The Area is located on the premises of the German Hospital (Corniche El-Nil). The excavation took place from March $26^{\text {th }}$ to May $4^{\text {th }}$ 2009. It was conducted by the Swiss Institute under the supervision of W. MÜLLER.
} 
different: In the north the wall was $0.6 \mathrm{~m}$ wide and in its upper courses made of fired bricks. The western face of the wall was coated in white lime plaster. In the southern part the fired bricks were not preserved any more and the wall was significantly wider (1m).

Approximately $3 \mathrm{~m}$ to the south of the northern corner a narrow gate entered the wall. The gate was 1.30 wide, more than $4 \mathrm{~m}$ high and roofed with a double arch. The inner arch was made of fired bricks, the outer one of simple rectangular sandstone-blocks held together by lime-mortar (fig. 28).

To the north of the entrance the wall was resting on a granite-outcrop. The granite-boulder was obviously isolated as a massive stepped platform made of reused sandstone blocks had to be constructed as a base for the southern part of the wall. The platform itself had a bedding of rosegranite rubble. Due to the high water-table the bottom of the foundation was not reached. The width of the platform was $0.30 \mathrm{~m}$ at the gate and 0.70 in the south, where it was limited by the projection of the wall (fig. 29).

A building joint, $5.20 \mathrm{~m}$ south of the northern corner marks the border between a northern and southern room, built into the embankment. The preserved depth of the northern room was $0.70 \mathrm{~m}$, its north-south extension was 4.15 , its width $2 \mathrm{~m}$ (the eastern and western wall were not parallel). A bench at its northern end (1.10m wide) with a rounded moulding on top probably served as support for transport vessels. The whole room, including the bench, was coated in thick limeplaster except for the area exactly on top of the vaulted gateway, where the lime-pavement was interrupted and a badly damaged small channel seemed to slope down towards the west. The water resistant coating of wall and floor indicates some kind of hydraulic function (fig. 30).

To the south of the building-joint another carefully plastered room was detected in the section to the east of the wall. This room was $2.5 \mathrm{~m}$ deep and showed several phases. The southern face of the southern wall of the northern room was coated in white lime-plaster, the northern wall of the southern room was abutting the plastered surface, therefore definitely later than the northern room. Due to the similar building-materials and the uniformity of the construction little time should have passed between the constructions of both rooms (fig. 31).

The face of the wall shows several changes in building material. To the north of the gate the lower three metres of the wall are made of small sandstone blocks. After a small offset the angle of the wall, it was now significantly straighter, and the building-material changed. The blocks used for this part of the wall were bigger and further apart (more mortar was used). The construction of the arch falls within this part of the wall. The arch is resting on the lower portion of the wall. The same type of sandstone was used for the construction of the upper $3.20 \mathrm{~m}$ of the wall to the south of the building-gap as in the lower part to the north of the gate. These blocks 
were similar to those reused in the Early Islamic building in Area 32. The lower 2.20m of the southern part of the wall were made of two layers of large rectangular blocks (1-1.20 x $0.40 \mathrm{x}$ $0.45 \mathrm{~m}$ ) resting on two layers of fragments of a Roman roof construction (14 fragments were retrieved). The lowest layer of blocks consisted of sandstone blocks of different sizes, two of them bearing Greek inscriptions (fig. 32). The platform was constructed of two layers of similar blocks, three of them with Greek inscriptions. The same kind of lime mortar was used for the whole wall. The extremely hard mortar contained a large quantity of ashes in order to be more water-resistant.

Interpretation and dating of the wall

A sequence of several layers connected to the wall was investigated to the west of the wall. A layer of sterile Nile sediment covered a massive layer of debris (fired bricks and sandstonerubble). This debris derived from the collapse and abandonment of the wall. Material from this massive layer and the alluvial layers under it was medieval in date. The wall was part of the Mamluk river embankment. The rooms on top of the construction most probably constitute water tanks supplied with water by an installation for water-lifting, a saqia (a huge water-wheel) in the vaulted corridor to the east of the gate. The installation was in use for a long period of time and repaired frequently until the wall was finally abandoned when the town moved further north and left the area of Graeco Roman Syene. Massive Nile floods deposited silt on top of the debris from the collapse of the wall during the $19^{\text {th }}$ century.

Reused architectural fragments and inscribed material

In Area 52 the exact location of the pre-modern river bank was detected for the first time. Besides this topographical information the most important result of the excavations in Area 52 were the retrieved spolia and inscribed blocks. Numerous fragments of Hieroglyphic inscriptions were among the small blocks used in the upper part of the wall. Six big sandstone blocks with Greek inscriptions were reused in the lowest course of the southern part of the wall and the platform under it. The inscriptions suffered significantly from their prolonged exposure to the water of the river Nile. The current situation with a changing water table and the depth of the trench (more than $8 \mathrm{~m}$ below street level) and the danger to the hospital to the east led to the decision of the SCA to dismantle the wall and salvage the reused blocks. They have to be cleaned and conserved 
before any interpretation is possible. Palaeography gives a date in the fourth century for a large block (fig. 33) and later dates for the remaining inscriptions. ${ }^{43}$

Both the inscriptions and the architecture, several fragments of an ornate Roman roof construction, are no common occurrence in Syene. They were parts of Late-Roman representative buildings. It is no coincidence that the centre of Roman Syene has been located in the immediate vicinity of Area $52 .{ }^{44}$ A pillar of the monumental architecture once occupying the riverbank can still be seen in situ, reused in the laundry room of the German Hospital few metres to the south east of Area $52 .{ }^{45}$

(W. Müller)

\footnotetext{
${ }^{43}$ The inscriptions are studied by STEFAn PFEIFFER (Trier) whom I thank for this preliminary information.

${ }^{44}$ H. JARITZ, 'Ein Bau der römischen Kaiserzeit in Syene', in M. KrAuSE, S. SCHATEN (eds.), THEMELIA. Spätantike und koptologische Studien Peter Grossmann zum 65. Geburtstag (Wiesbaden 1998), 155-168. ${ }^{45}$ Ibid., 156.
} 


\begin{abstract}
:
During the ninth season of the joint archaeological project of the Swiss Institute of Architectural and Archaeological Research Cairo and the Supreme Council of Antiquities Aswan in Syene/Old Aswan seven rescue excavations have been conducted (Fig. 1). The investigated sites cover a time span from the Middle Kingdom to the Mamluk Period. The most surprising discovery was part of a substantial domestic building of the Middle Kingdom in the centre of Aswan. In other sites rock inscriptions of the late Middle Kingdom, a segment of the Late Period town wall and tombs of the Roman and Byzantine Period were uncovered as well as a segment of the Medieval river embankment wall and a rural quarter at the northern limits of the Mamluk town.
\end{abstract}




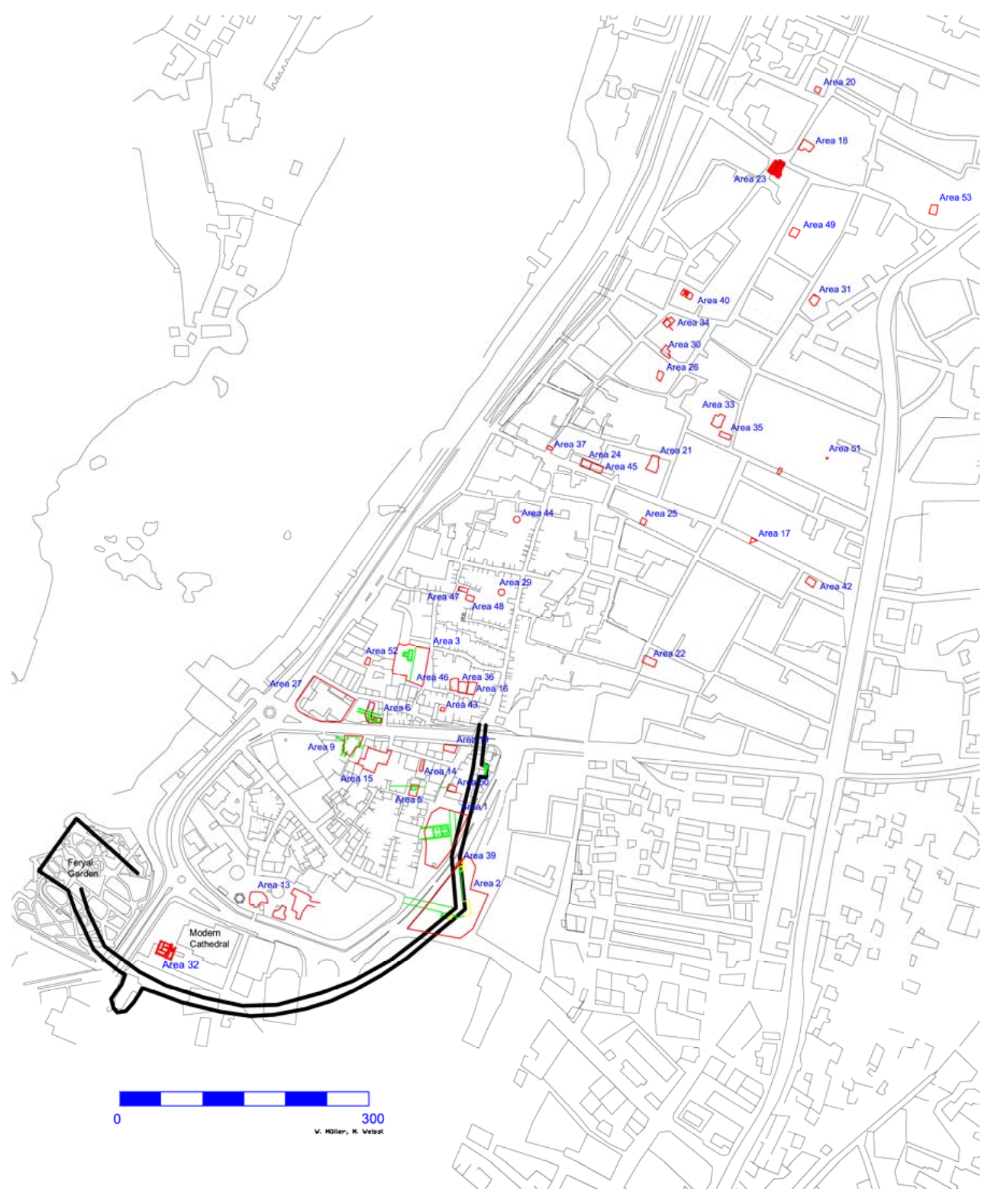

Fig. 1: Archaeological map of Aswan. 


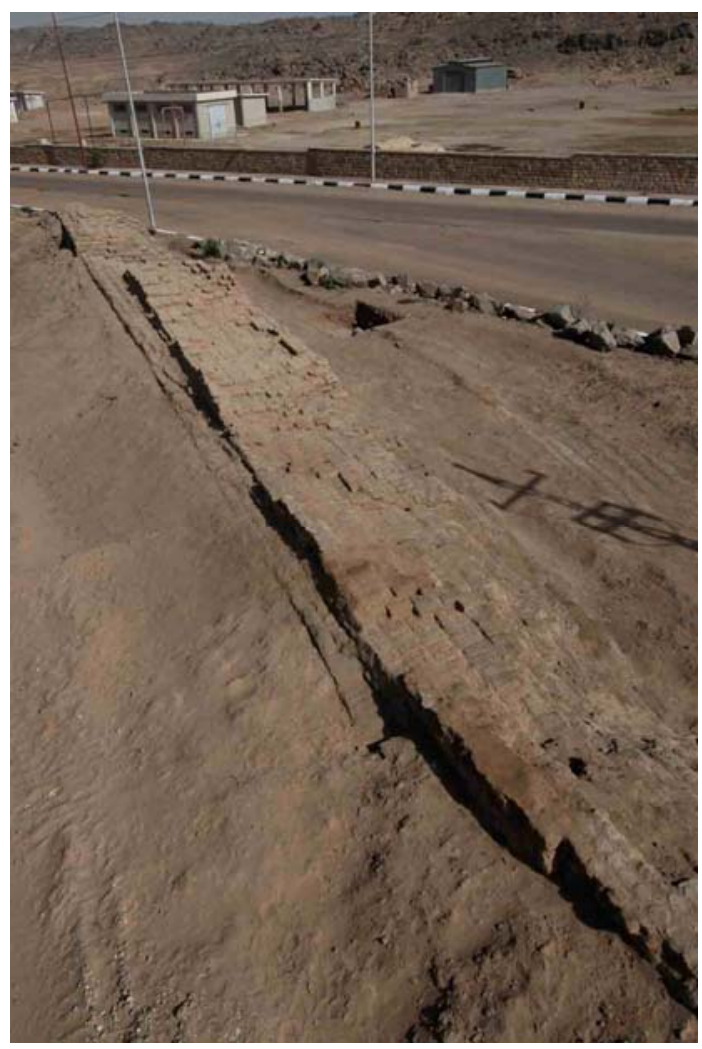

Fig. 2: Area 41: Overview on the fortification wall after cleaning.

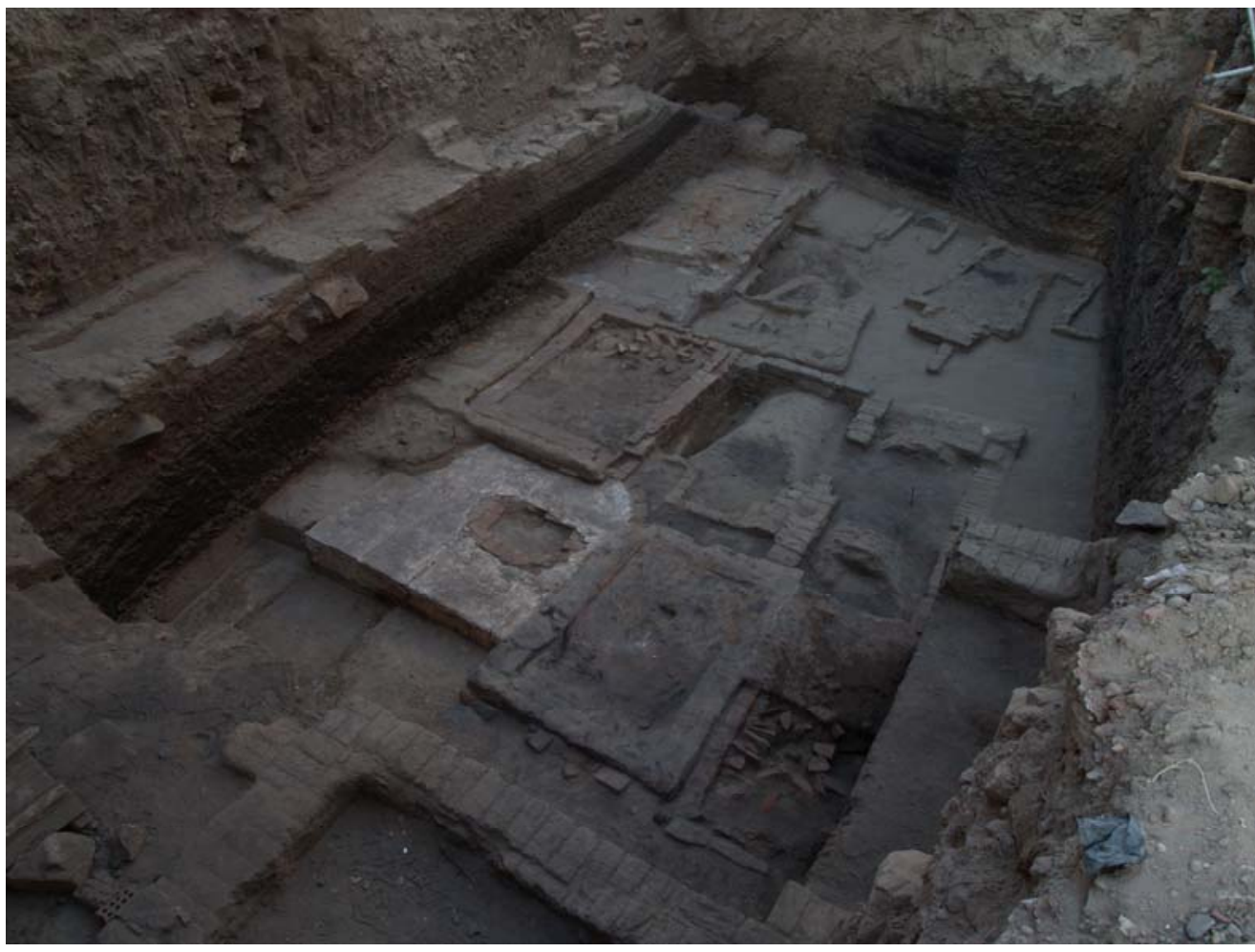

Fig. 3: Area 45: Late Roman cemetery in the western sector. 


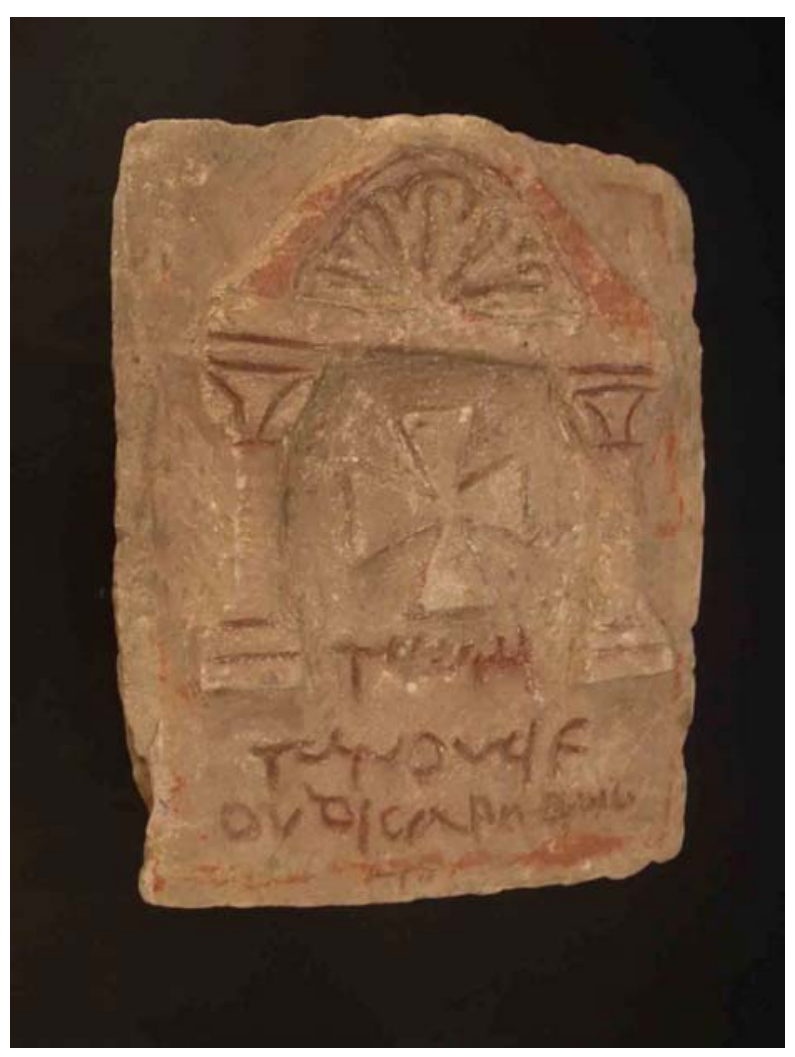

Fig. 4: Area 45: Late Roman funerary stela.

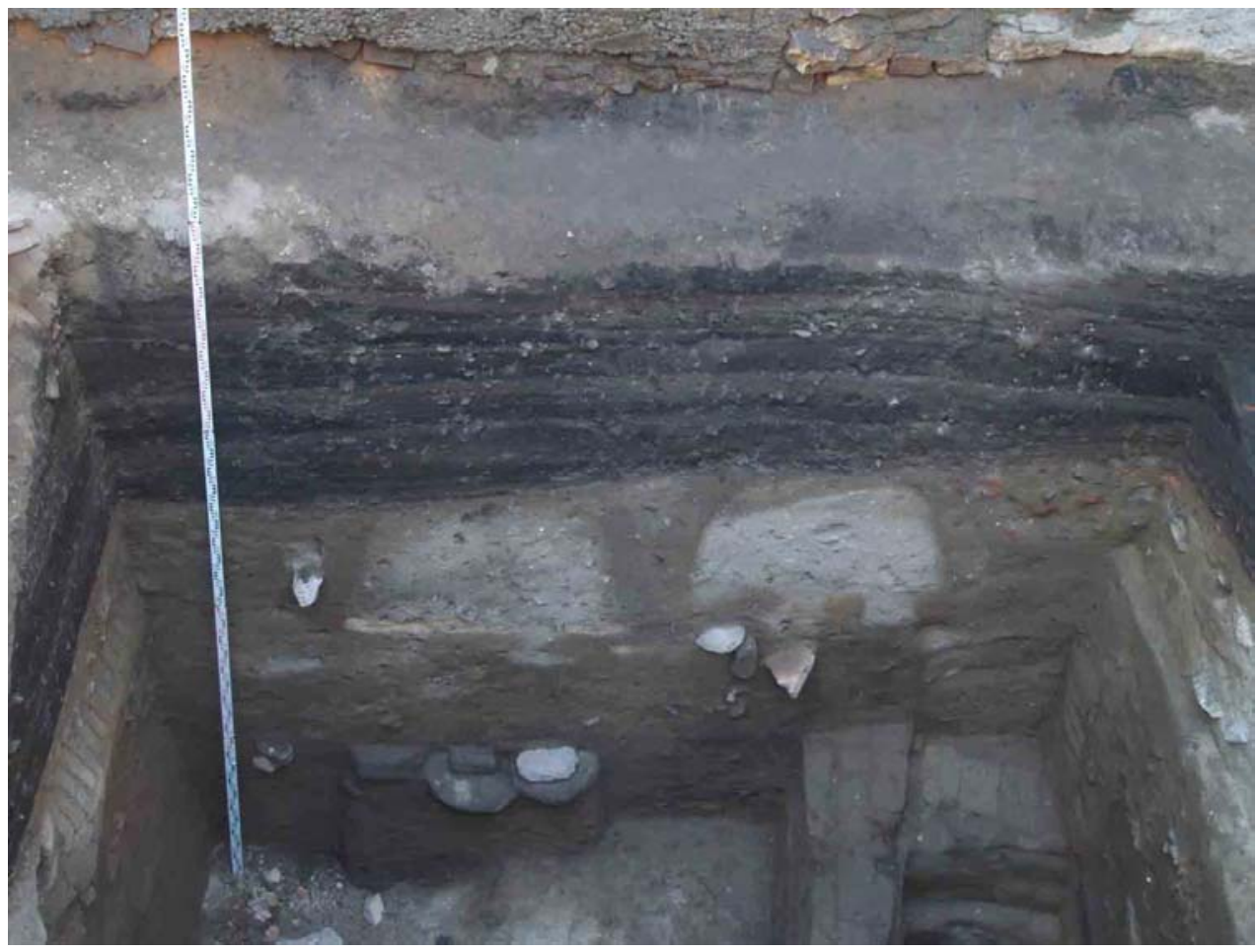

Fig. 5: Area 45: Western section of the eastern extension. 


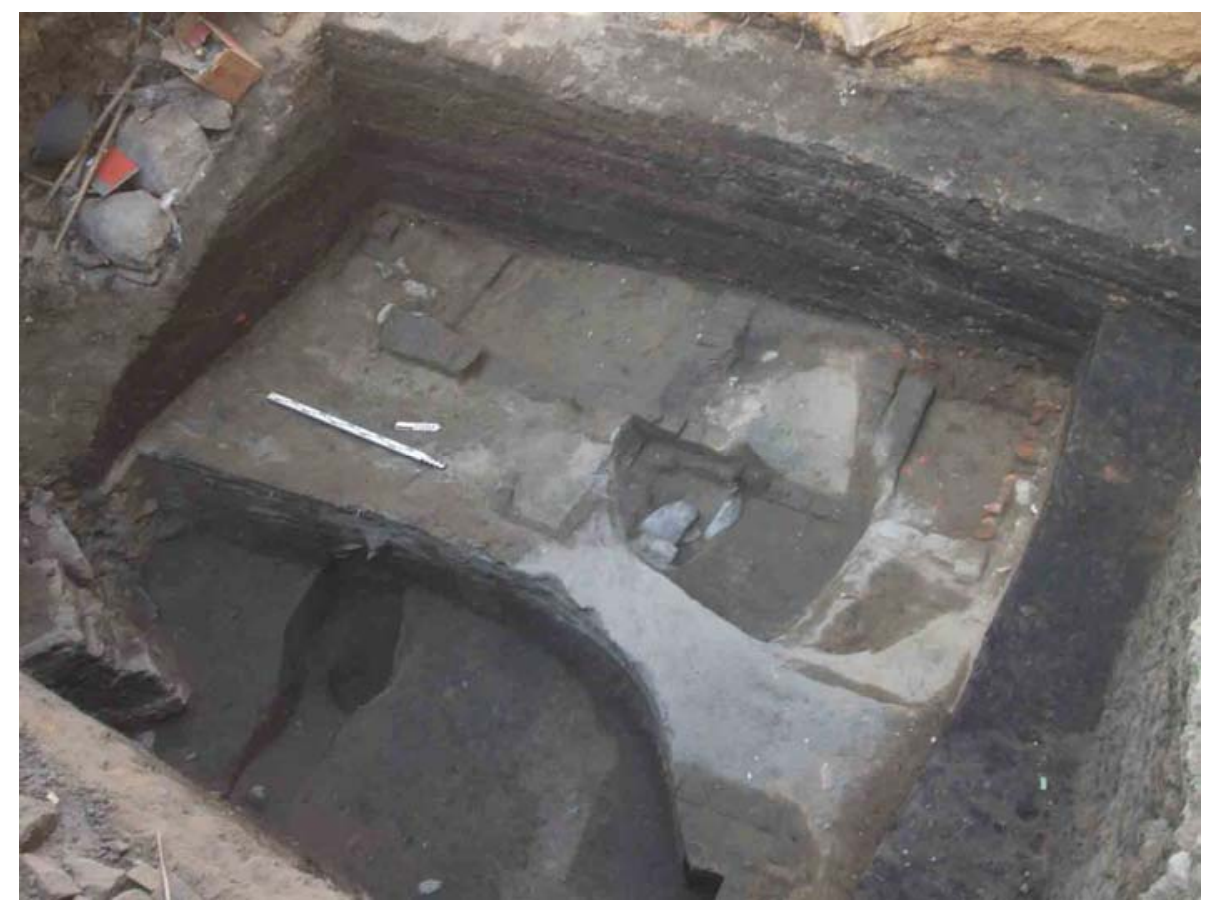

Fig. 6: Area 45: Tombs 1, 2 and 10.

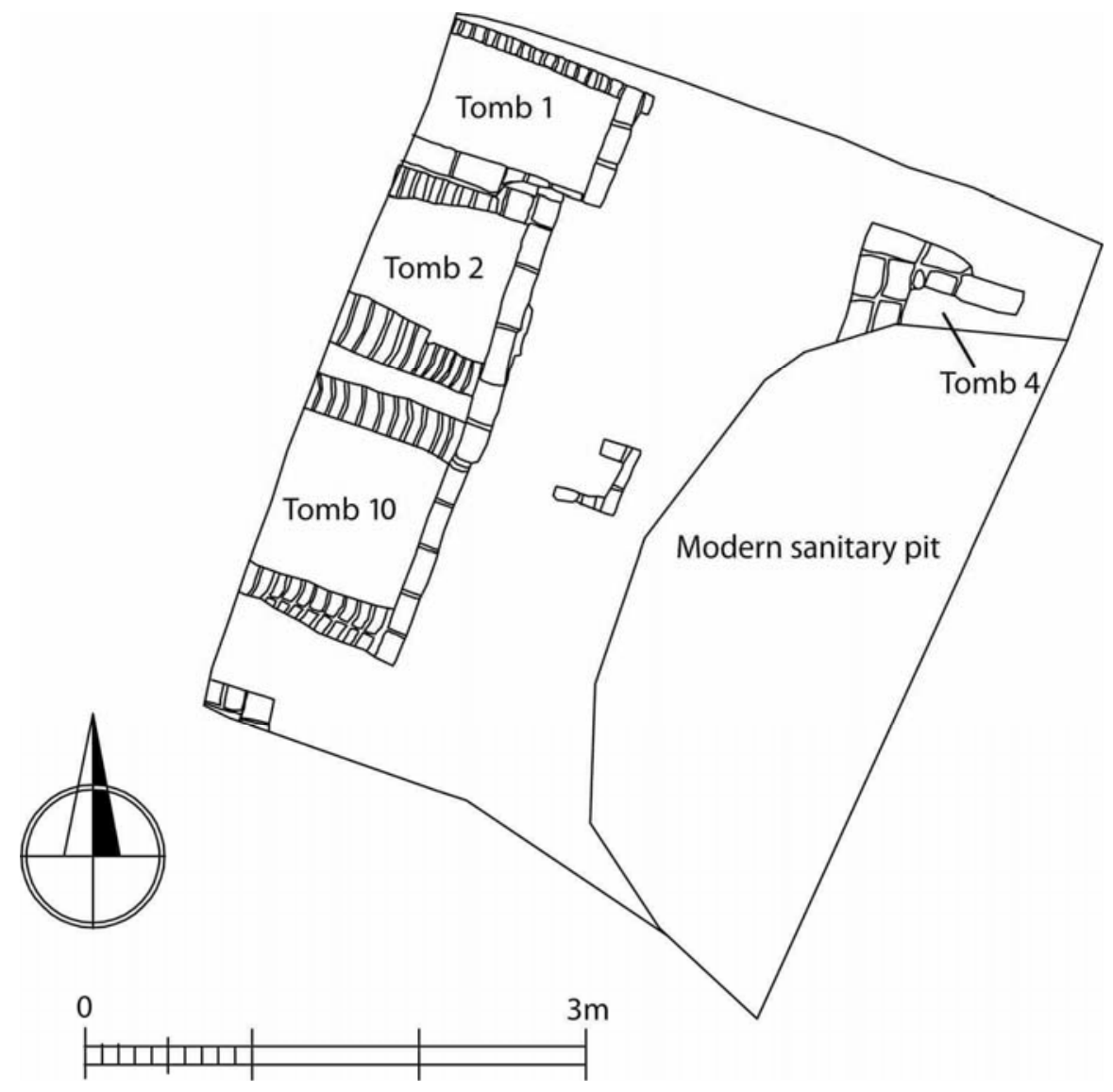

Fig. 7: Area 45: Plan of the Late Roman cemetery. 


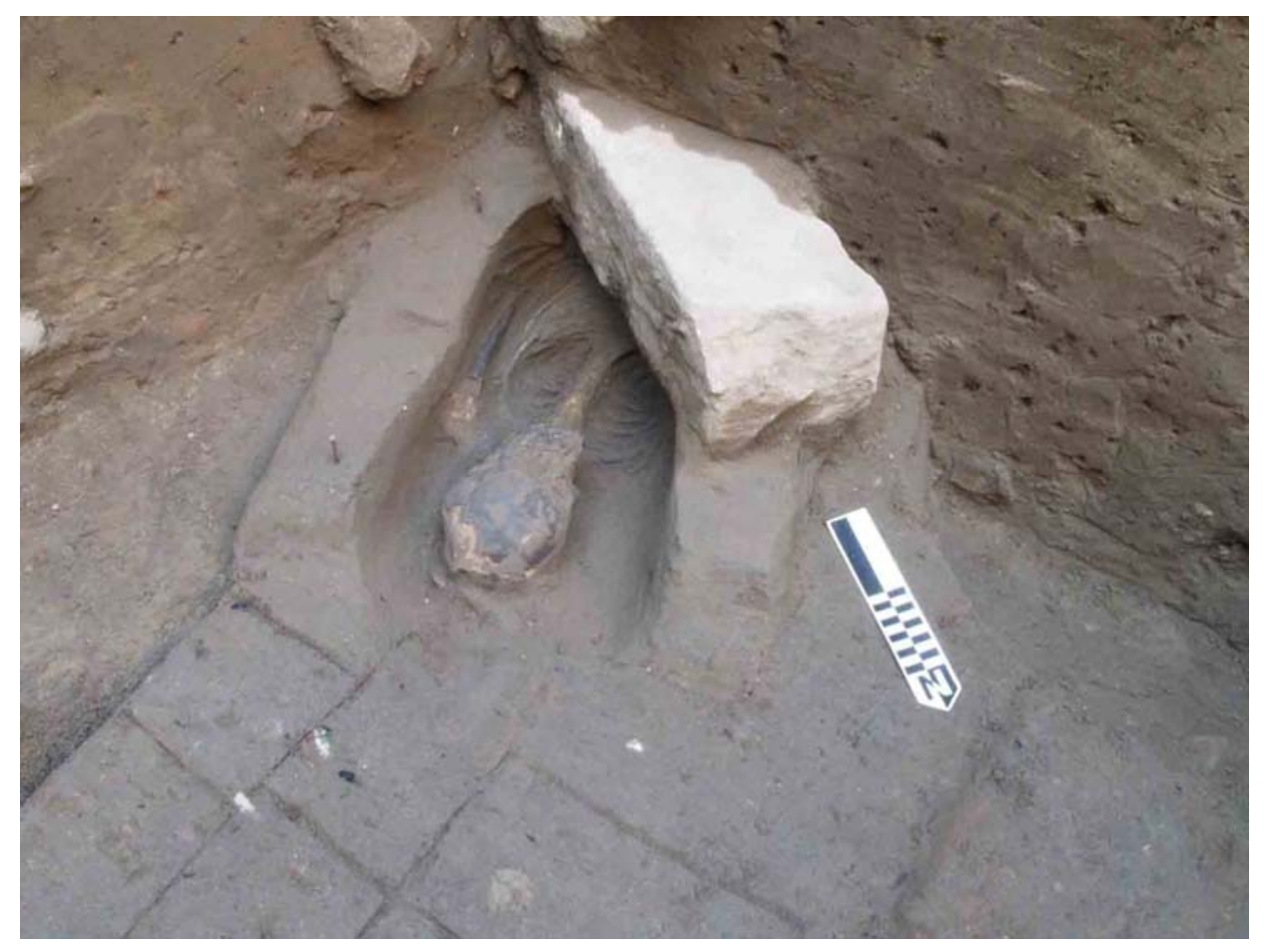

Fig. 8: Area 45: Grave of the earliest burial phase.

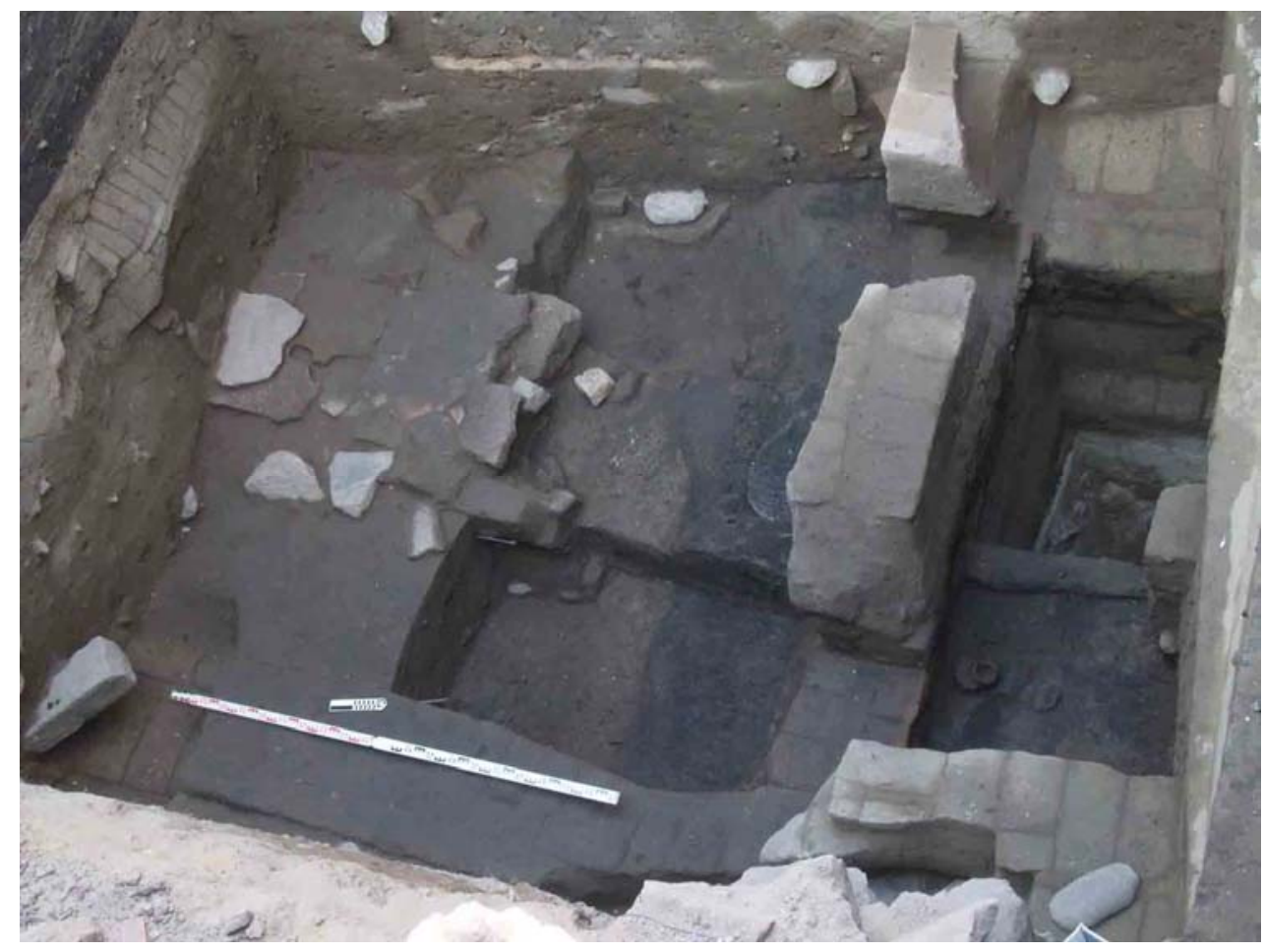

Fig. 9: Area 45: Overview of the Middle Kingdom structures. 


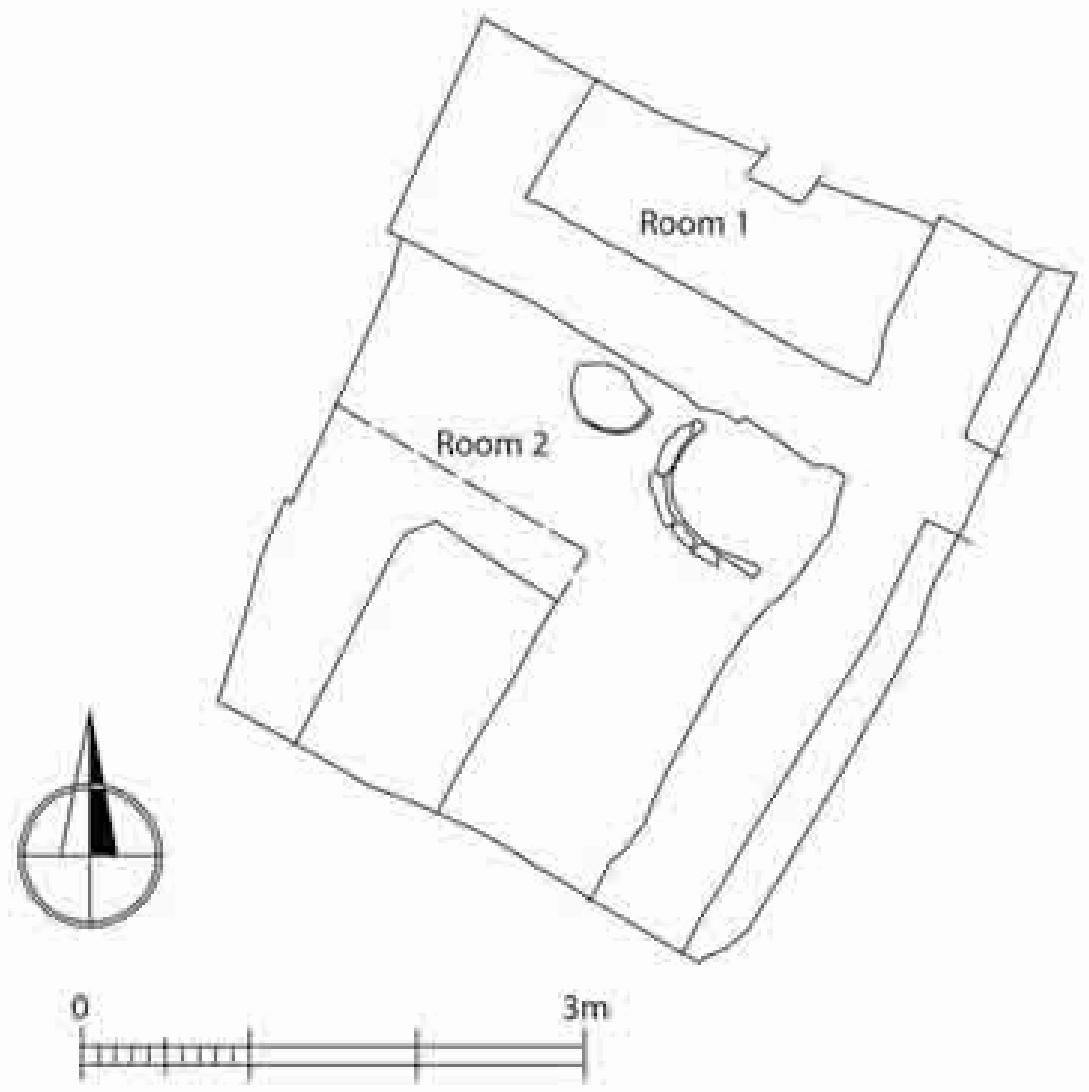

Fig. 10: Area 45: Plan of the Middle Kingdom structures.

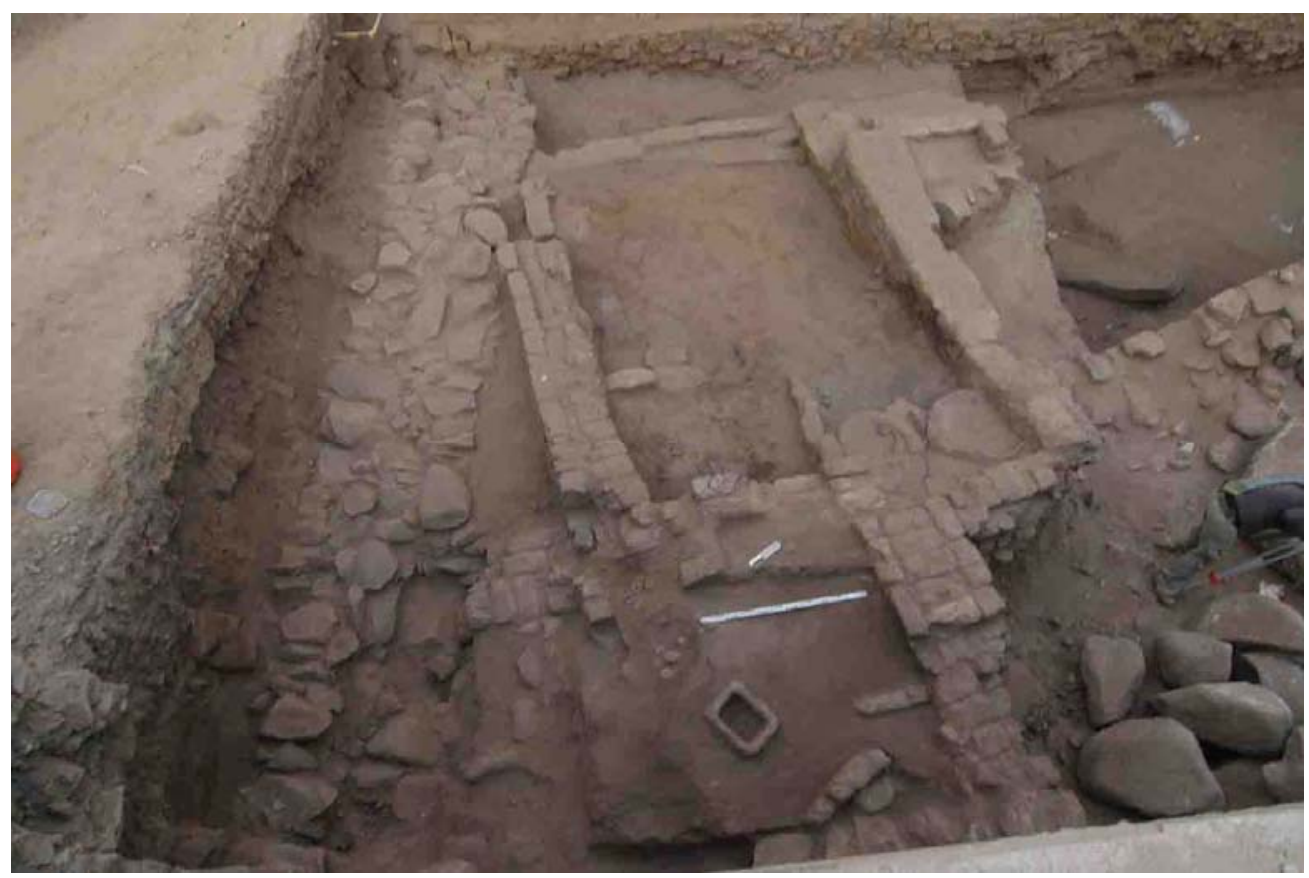

Fig. 11: Area 46: Overview of the Ptolemaic house. 


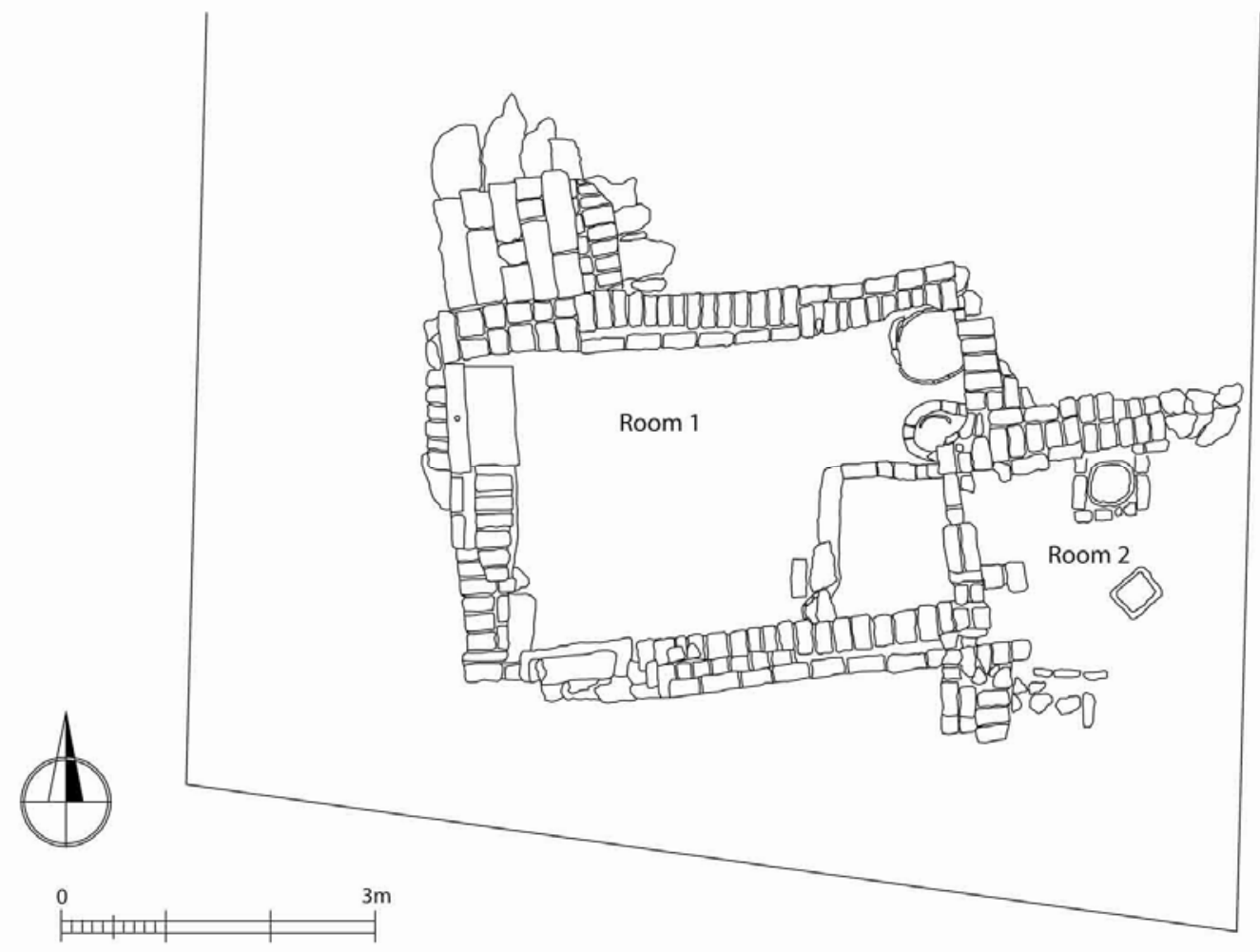

Fig. 12: Area 46: Plan of the Ptolemaic structures.

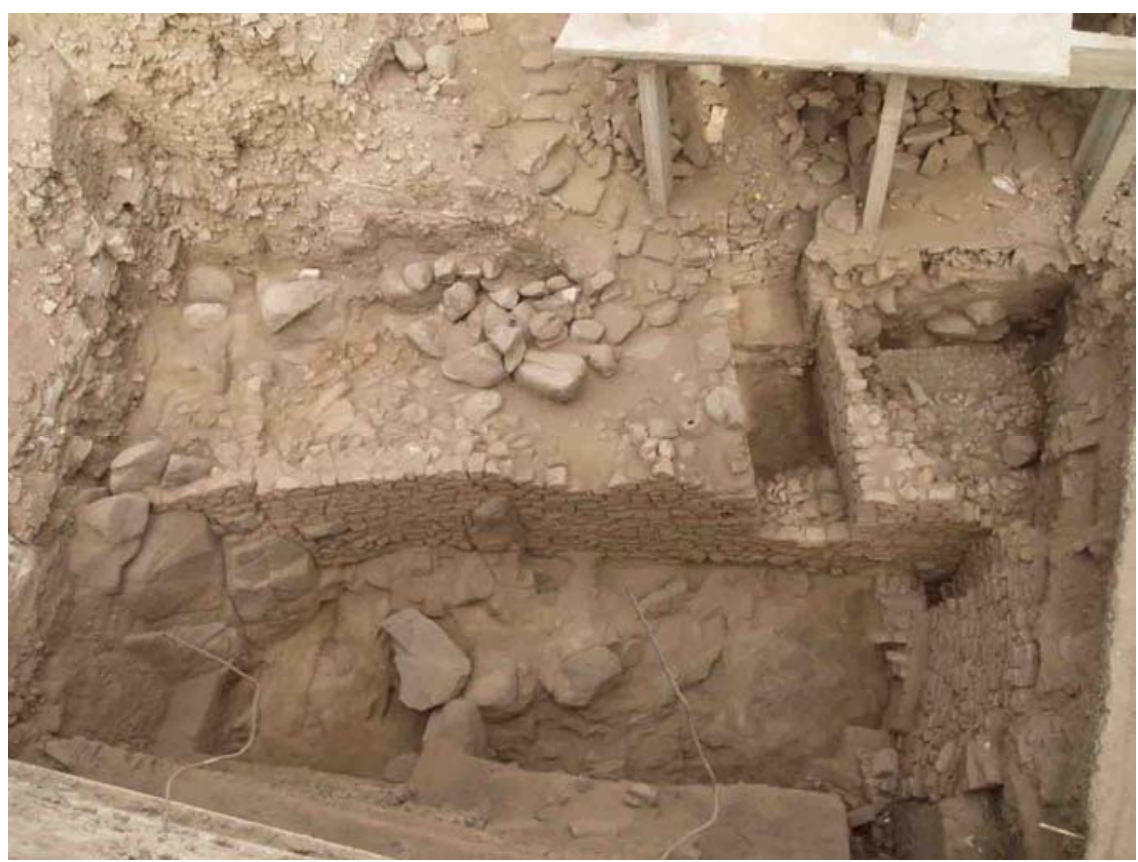

Fig. 13: Area 46: Overview of the city wall. 


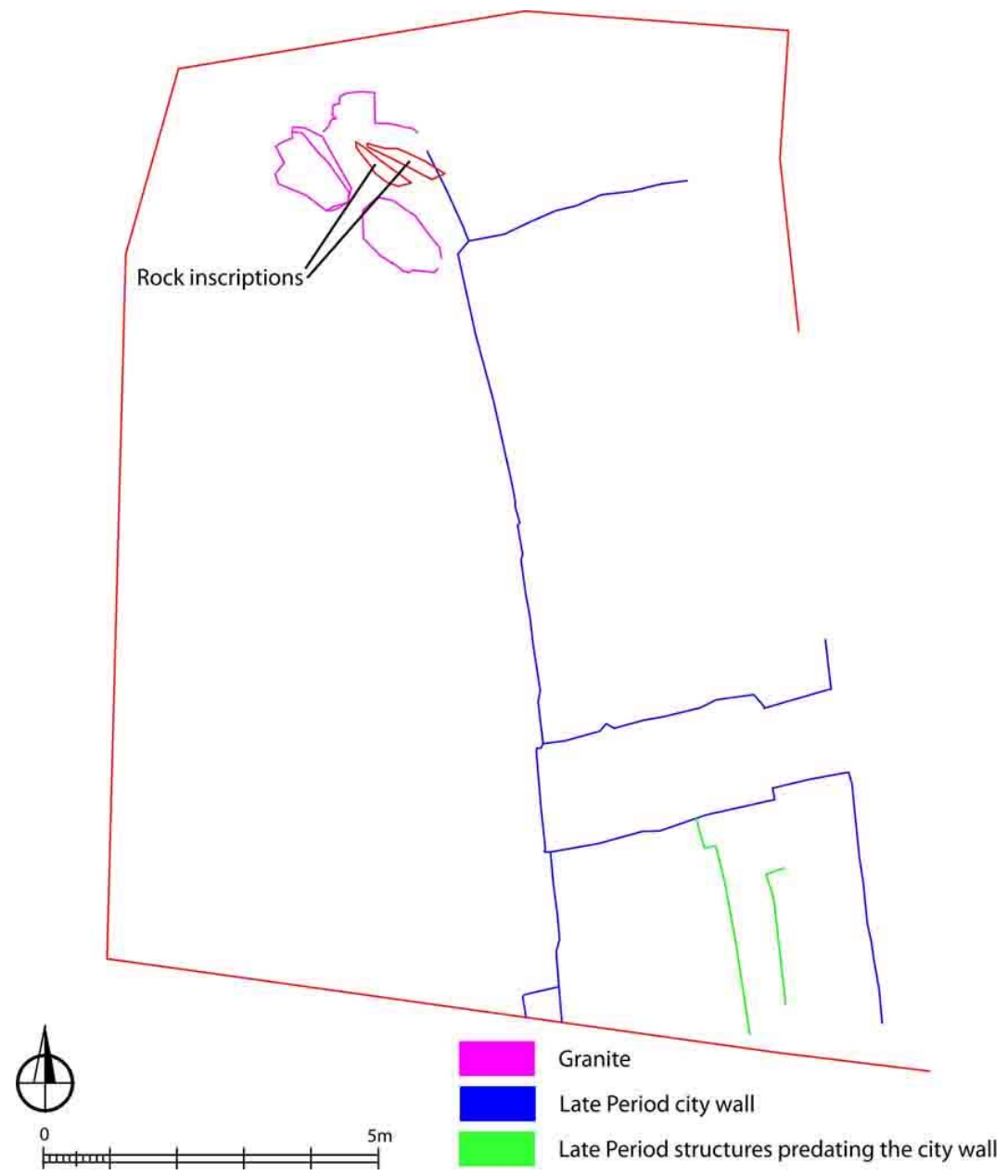

Fig. 14: Area 46: Plan of the city wall.

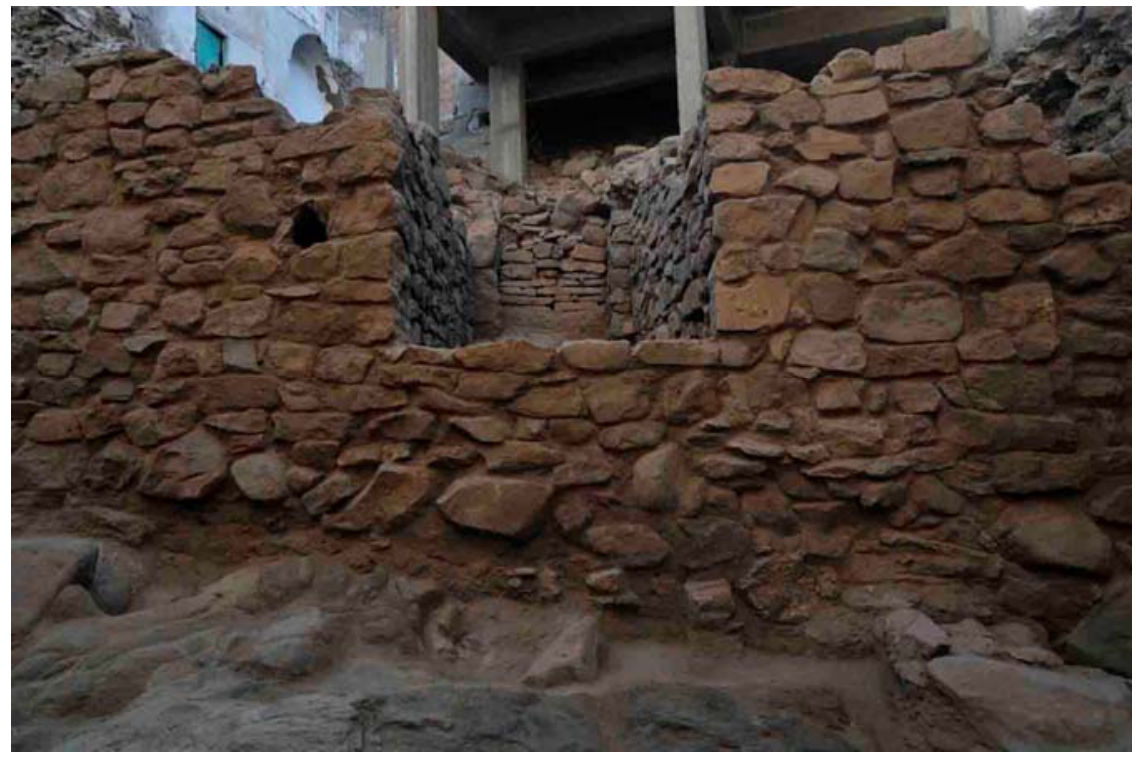

Fig. 15: Area 46: View of the gate from the west. 


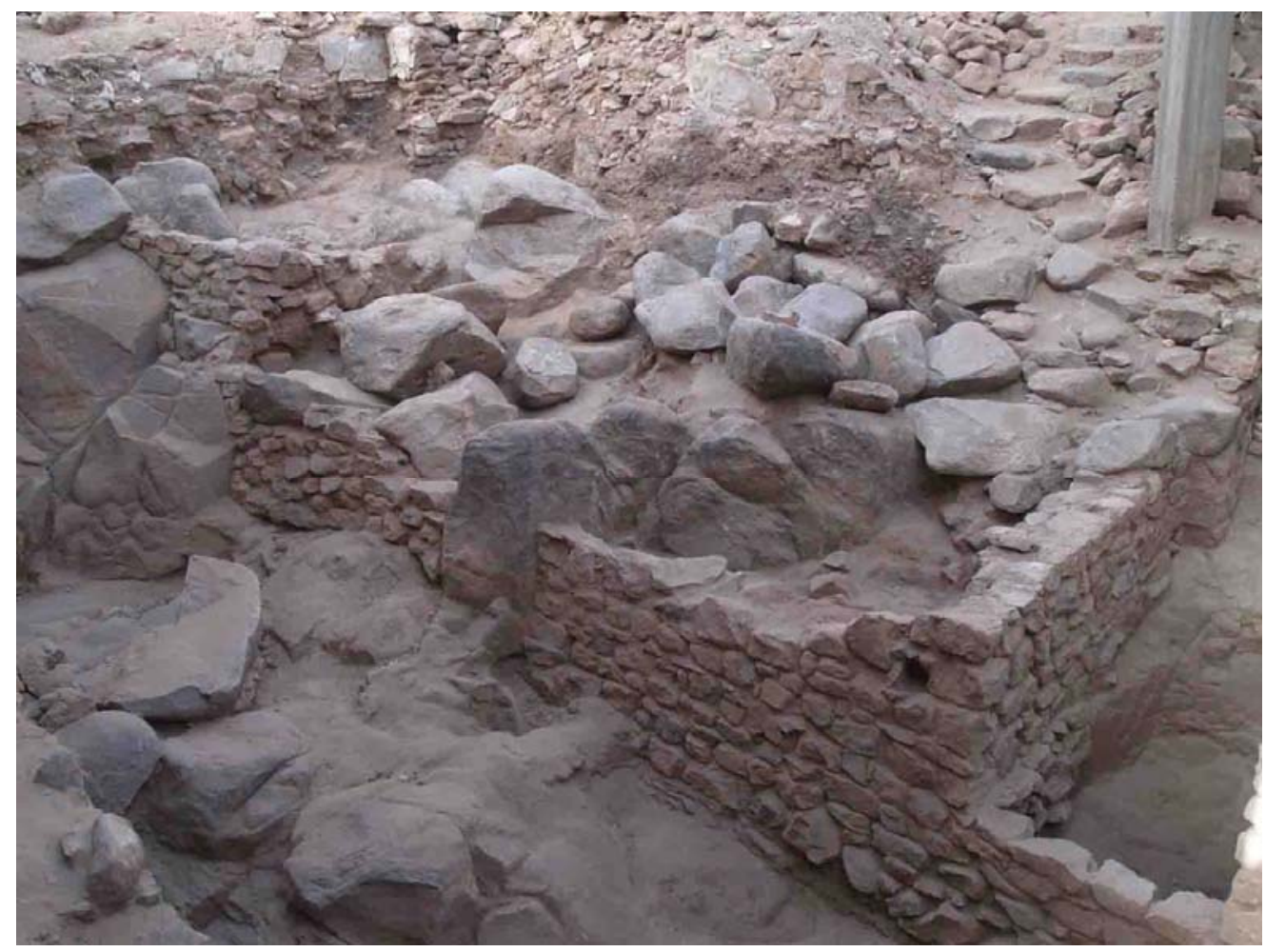

Fig. 16: Area 46: Dismantling of the Late Period wall.

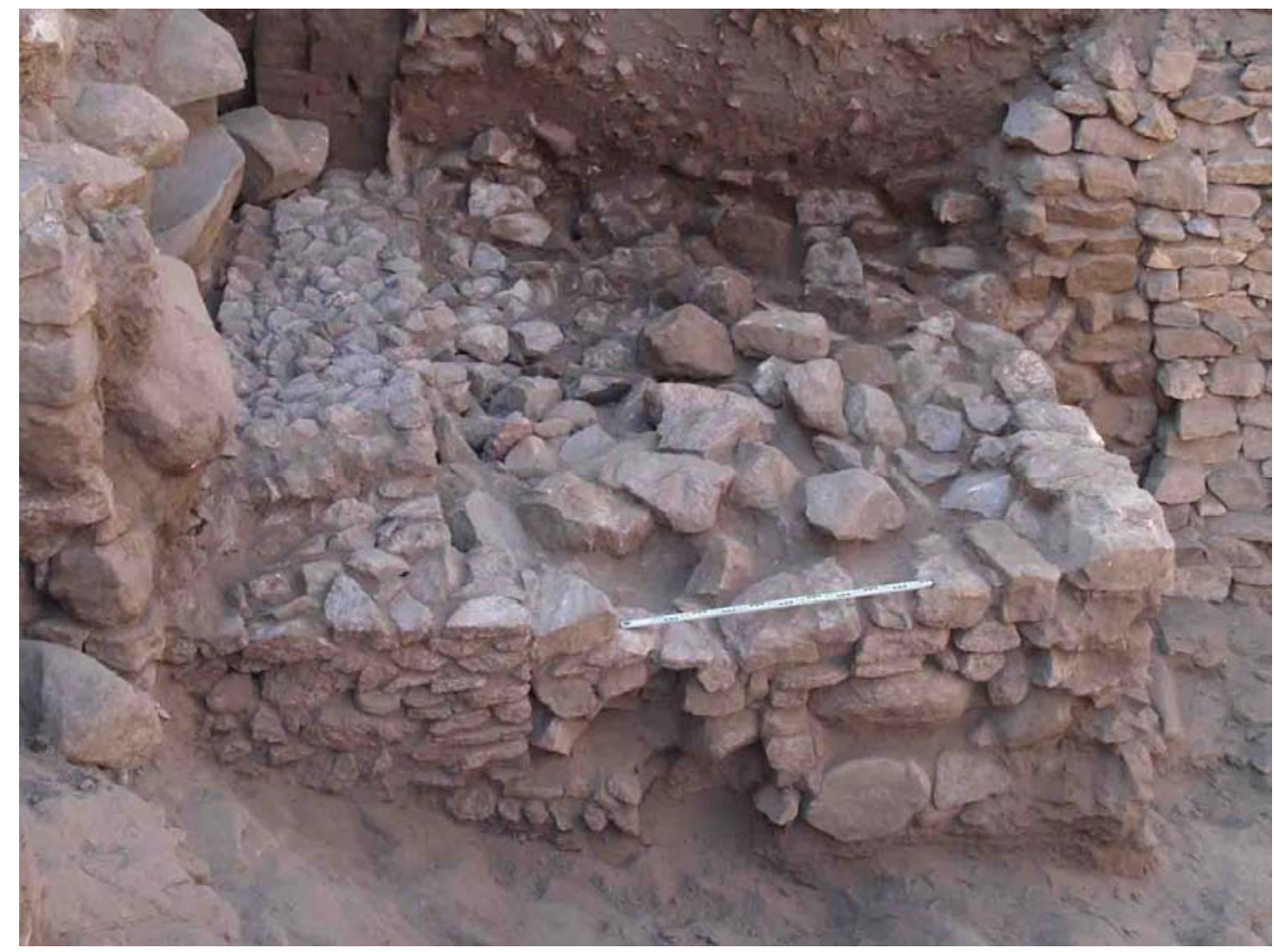

Fig. 17: Area 46: Earlier wall integrated into the body of the city wall. 


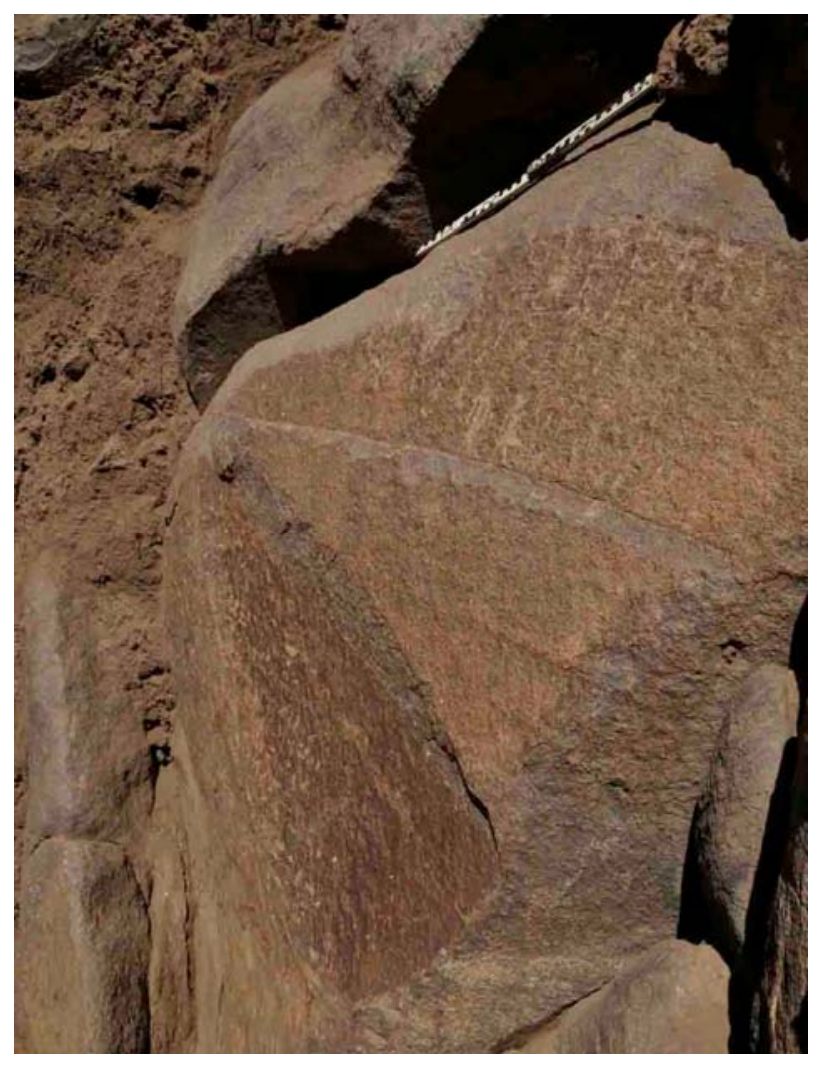

Fig. 18: Area 46: Rock inscriptions dating to Dynasty 13.

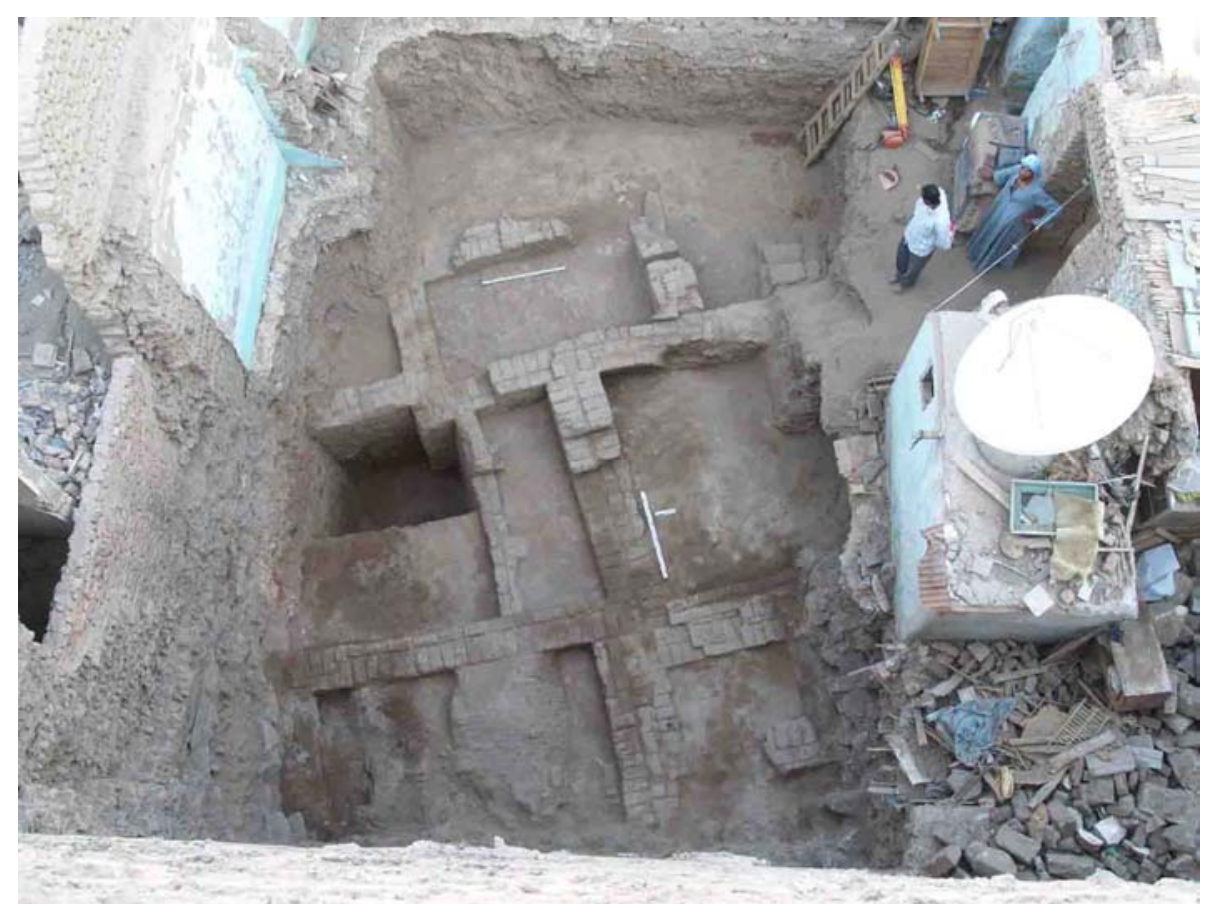

Fig. 19: Area 48: Overview of the Mamluk house. 


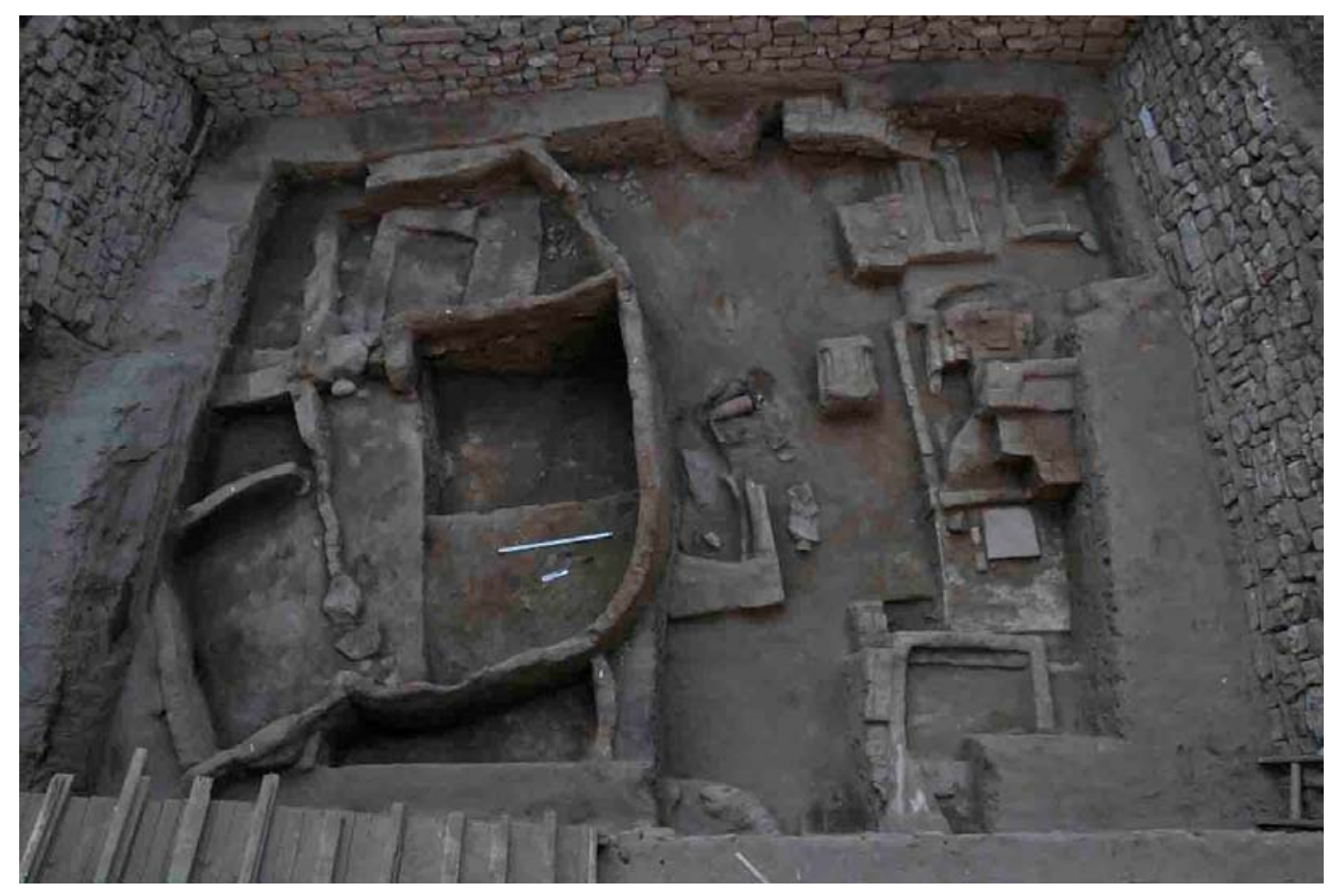

Fig. 20: Overview of Area 49.

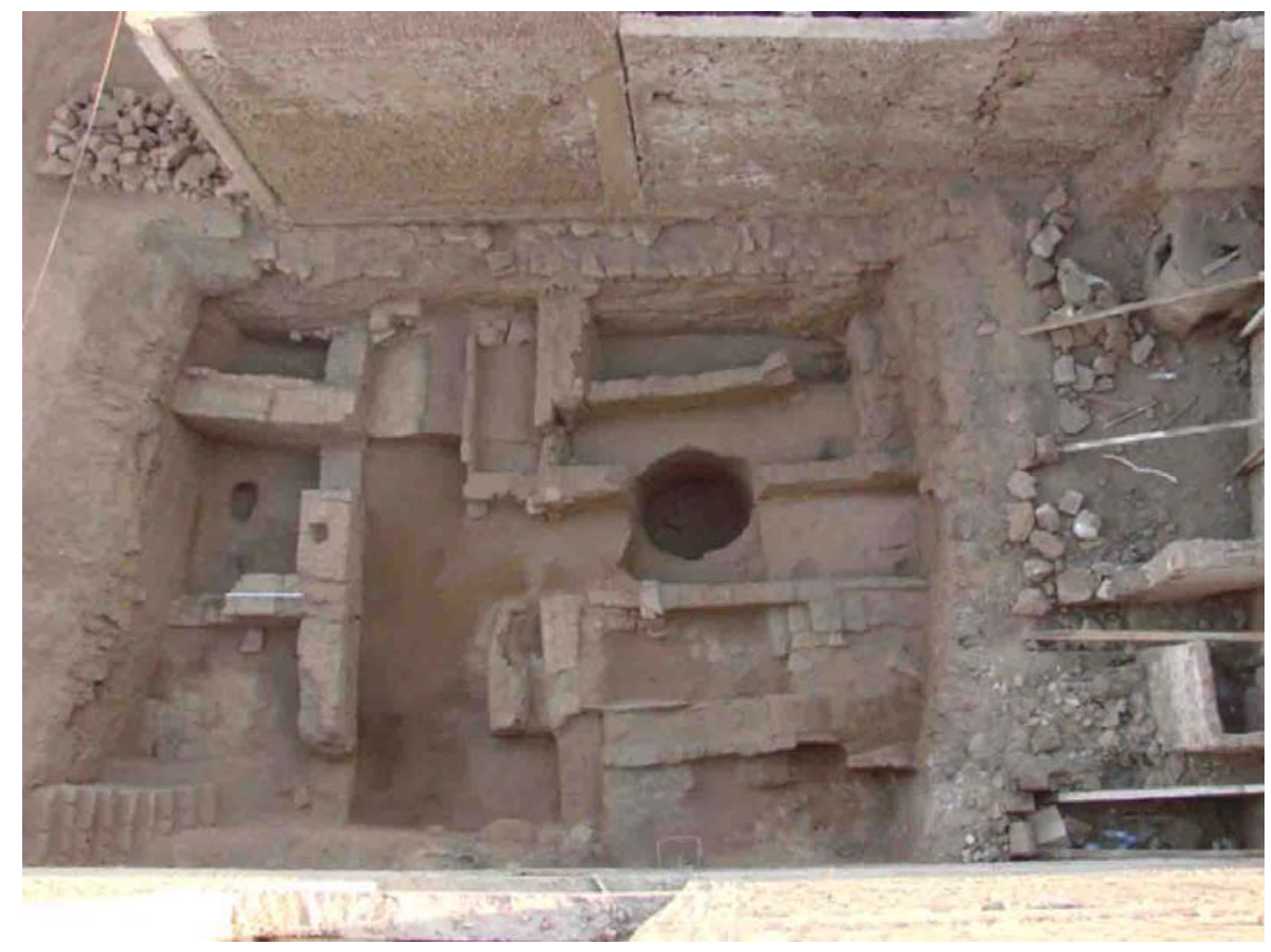

Fig. 21: Area 50: Overview of the Early Islamic city quarter. 


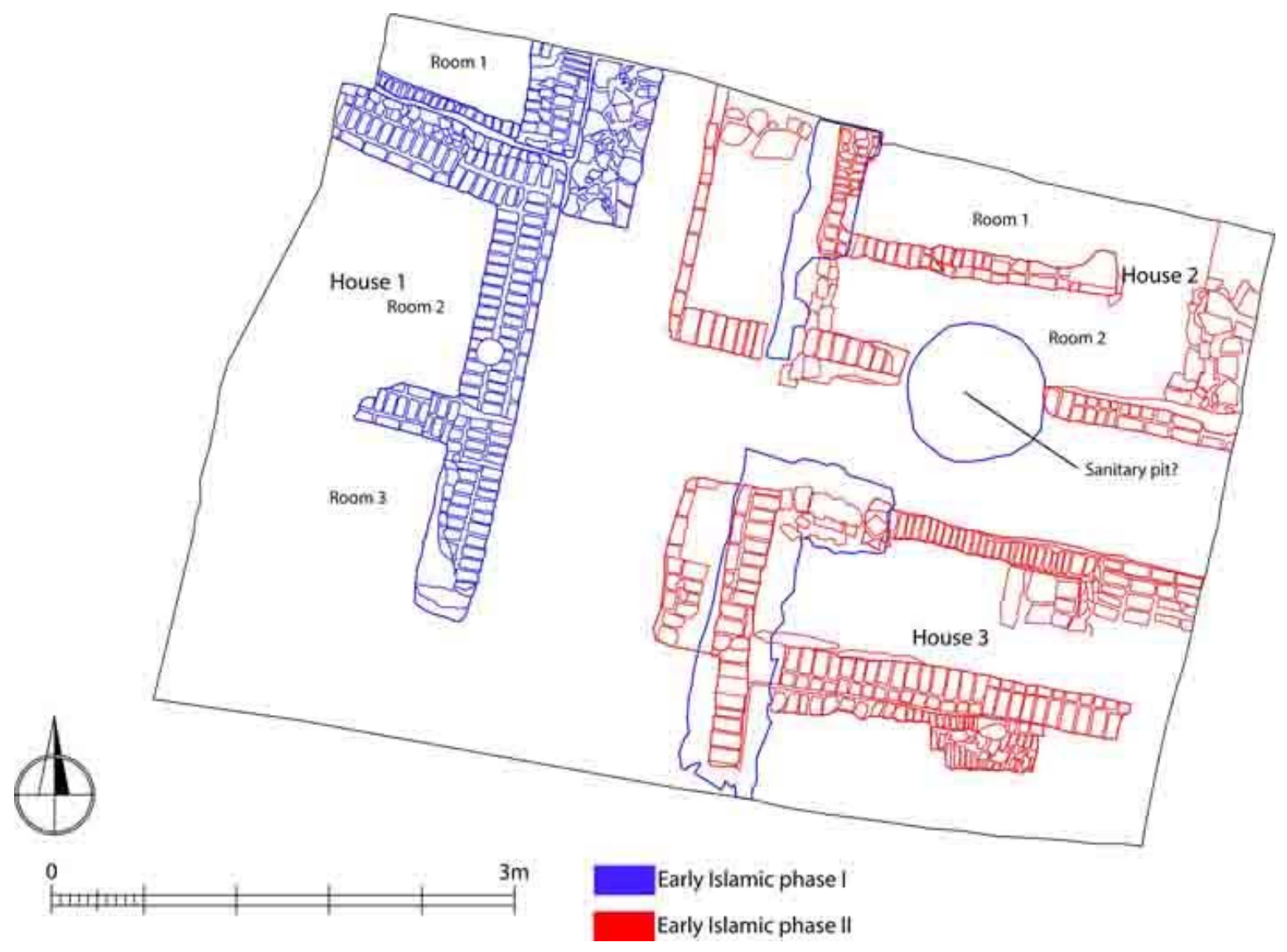

Fig. 22: Area 50: Plan of the Early Islamic phase.

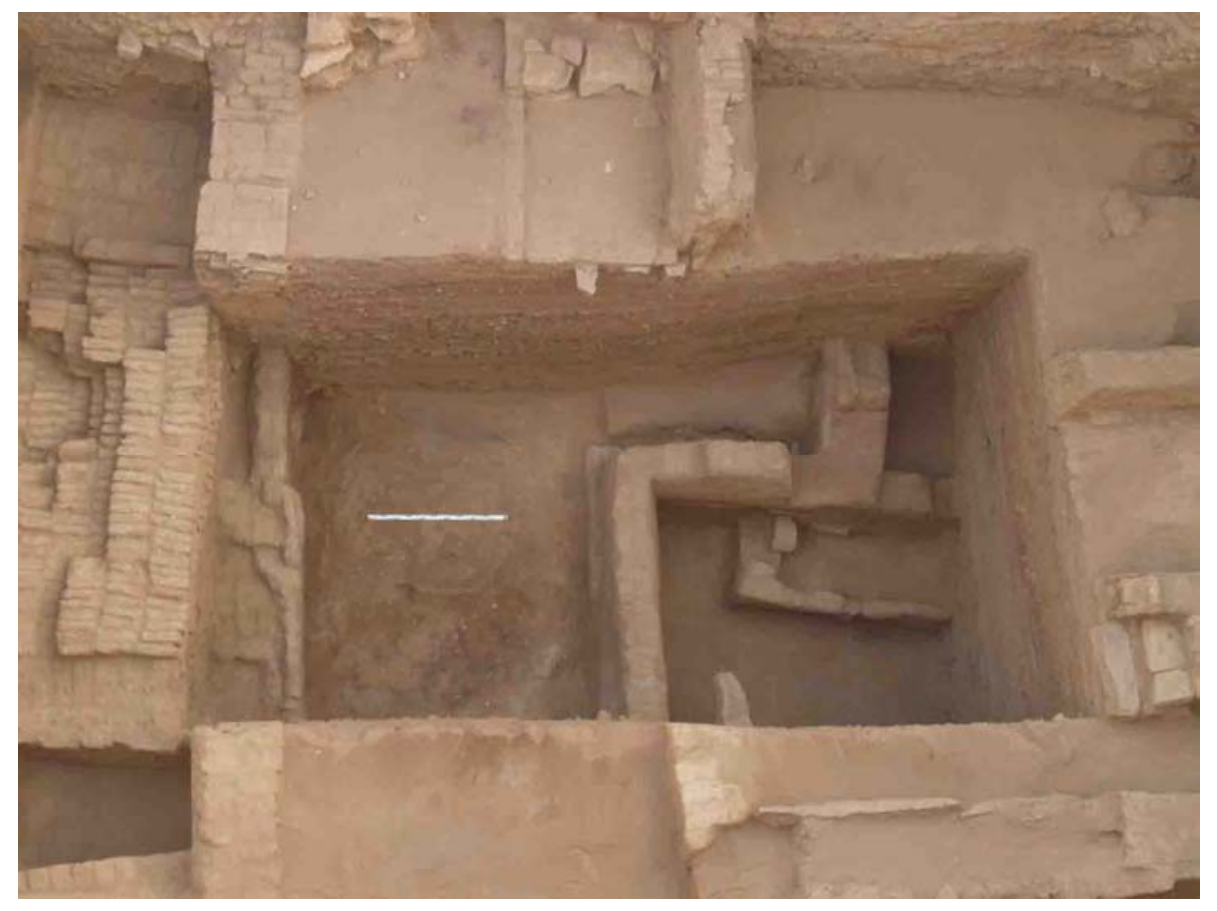

Fig. 23: Area 50: Overview of the Late Roman structures. 


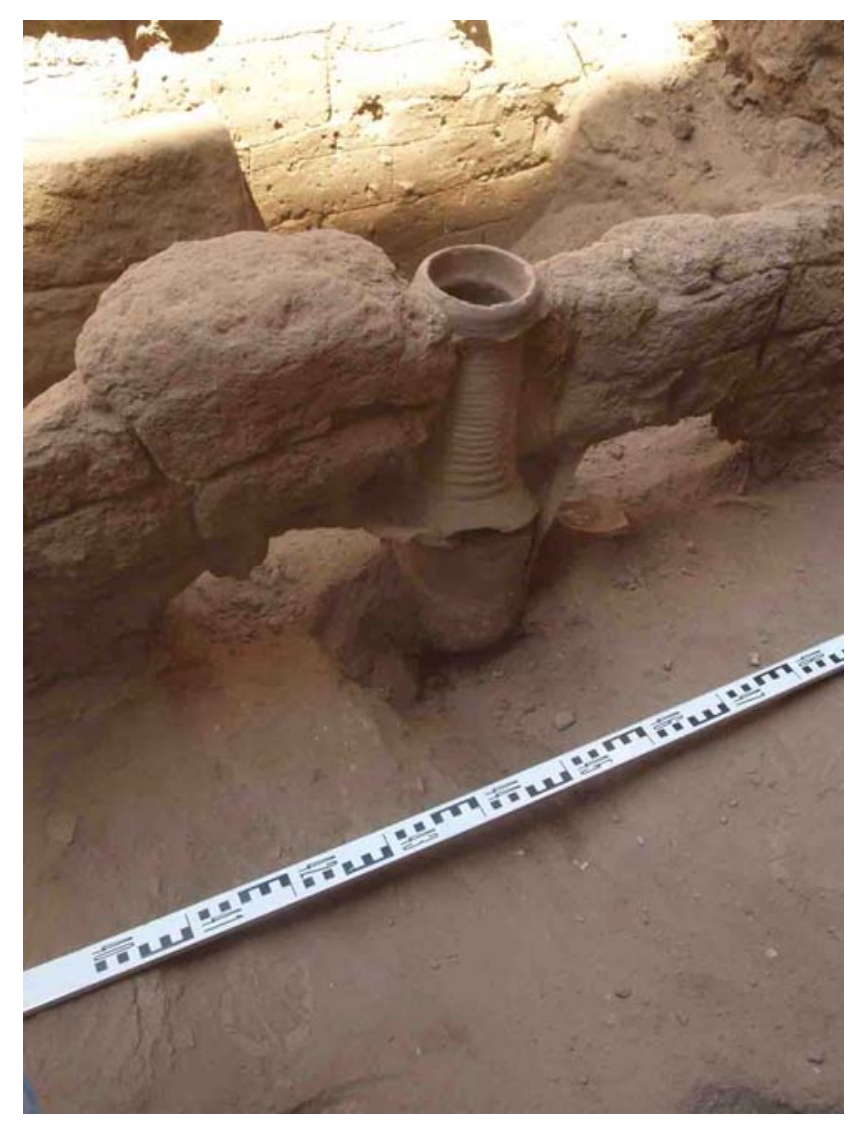

Fig. 24: Area 50: Late Roman Amphora integrated in a mud-brick wall.

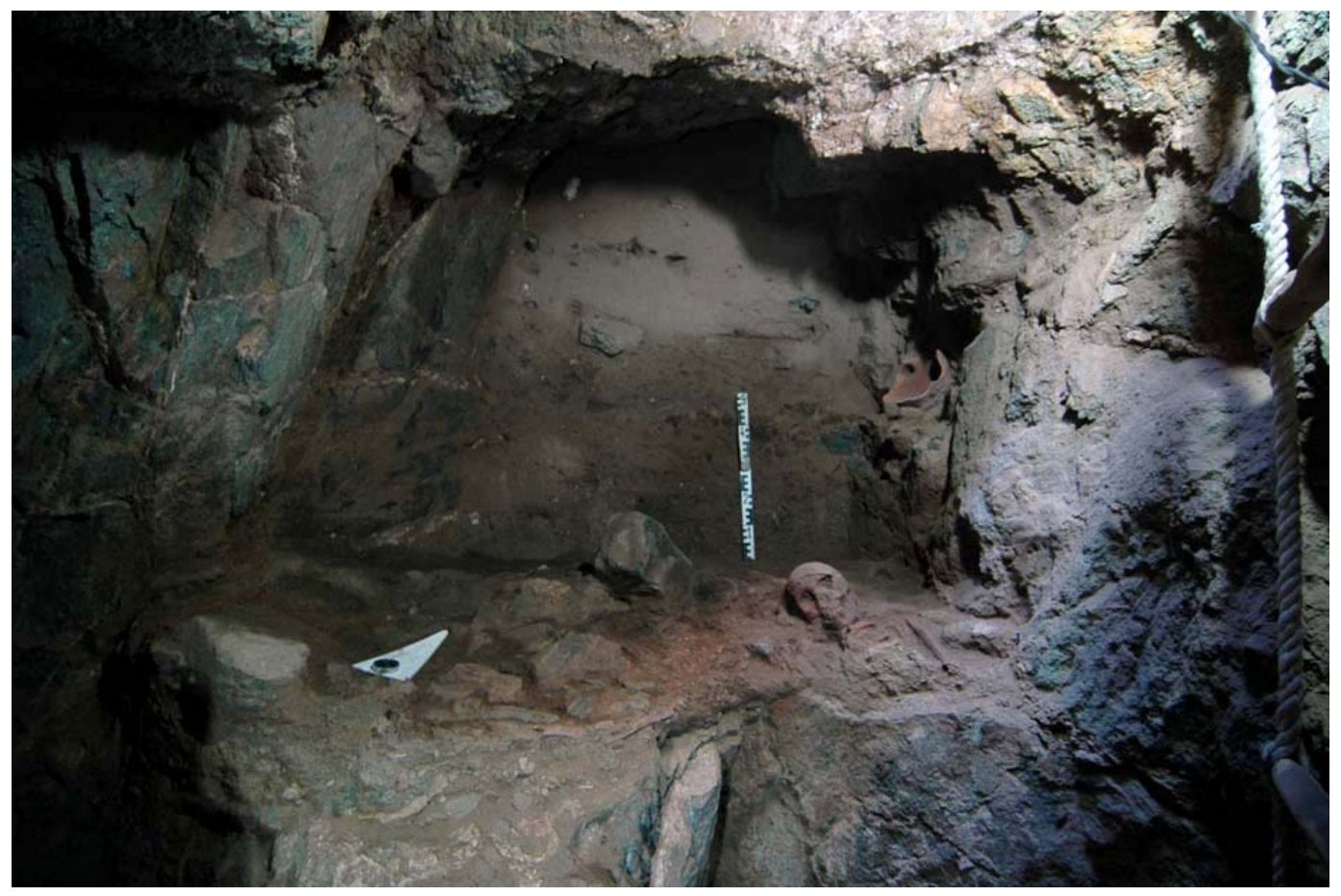

Fig. 25: Area 51: Partly destroyed burial in a rock tomb of the Roman Period. 


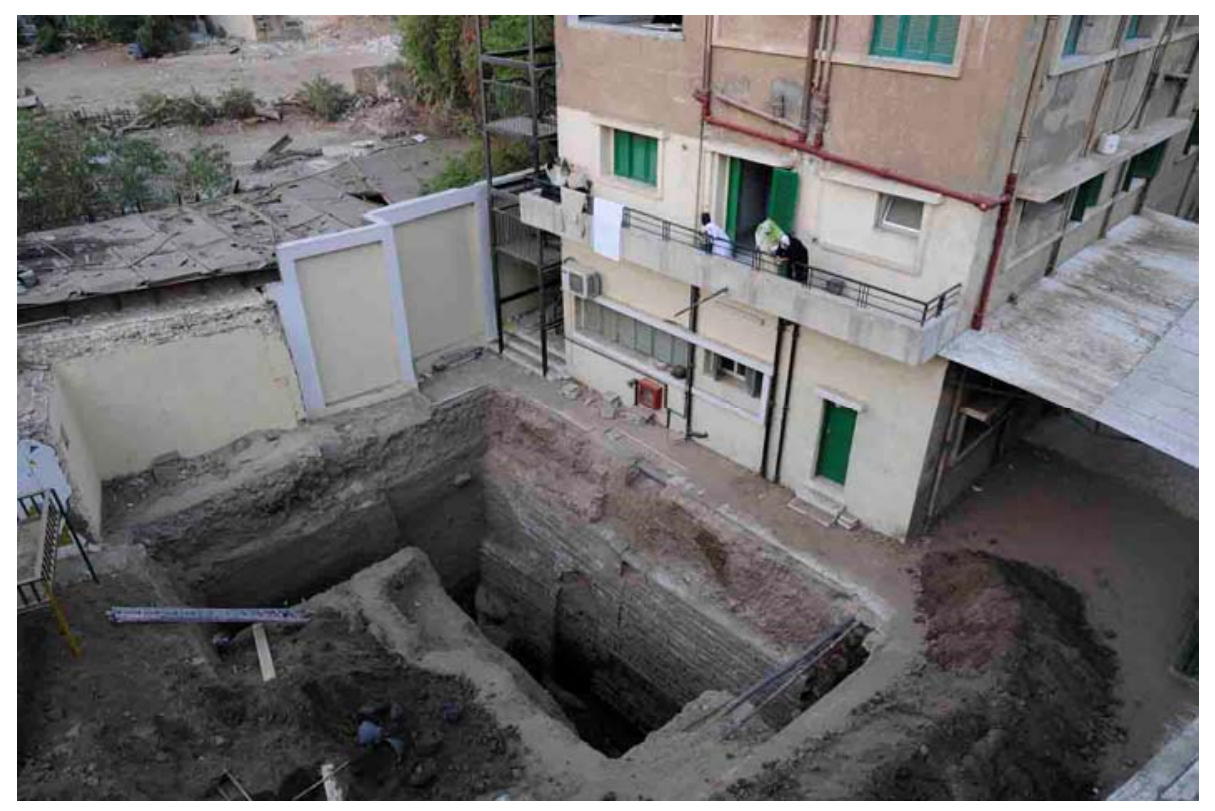

Fig. 26: Overview of Area 52

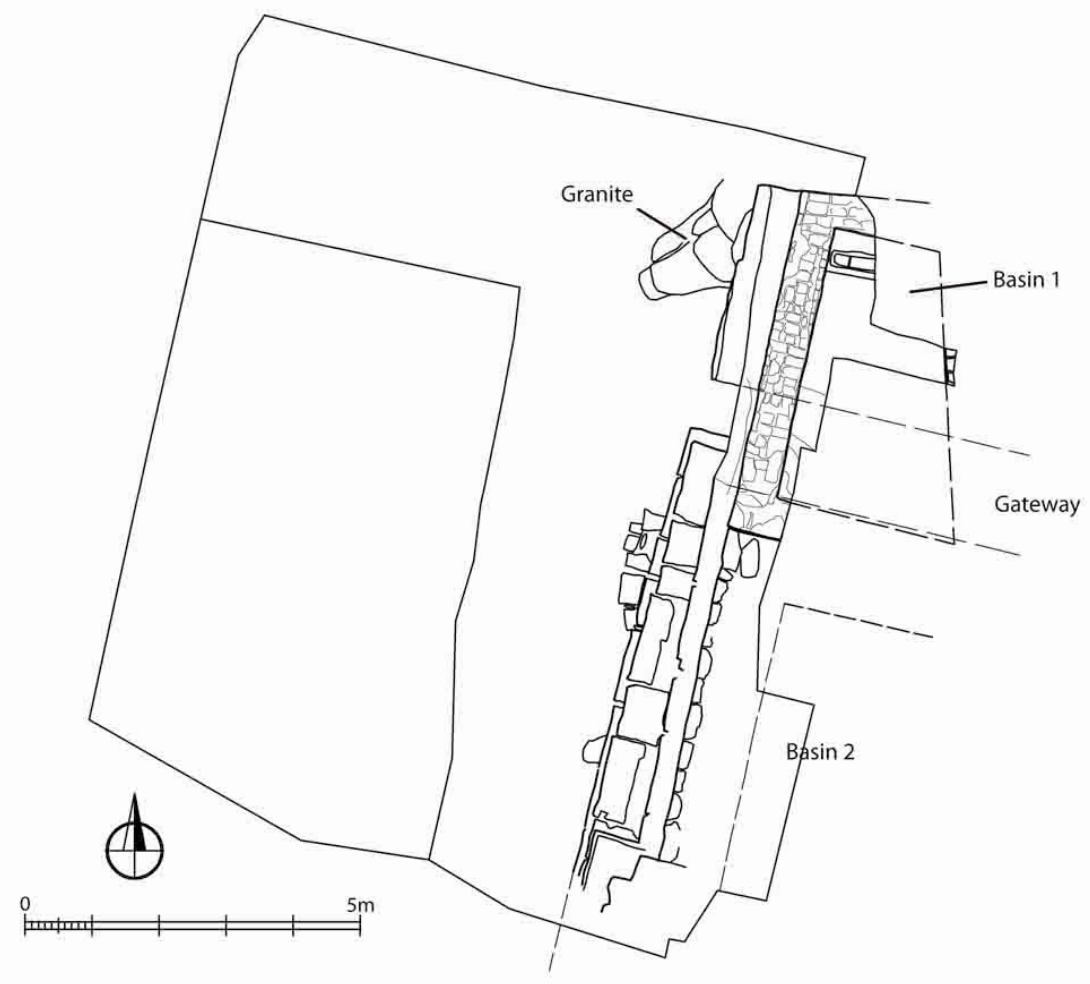

Fig. 27: Area 52: Plan of the medieval embankment wall. 


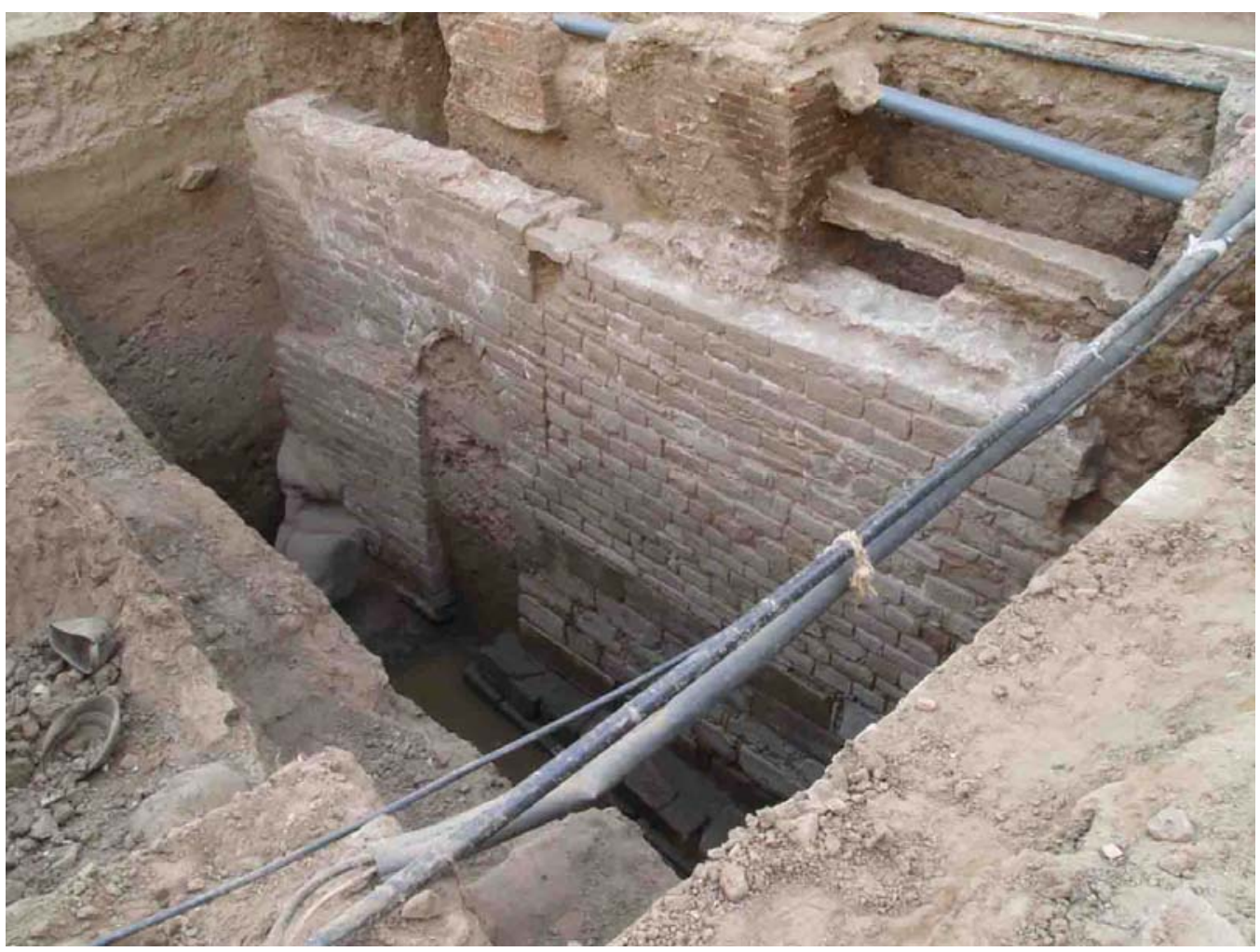

Fig. 28: Area 52: The western face of the embankment wall.

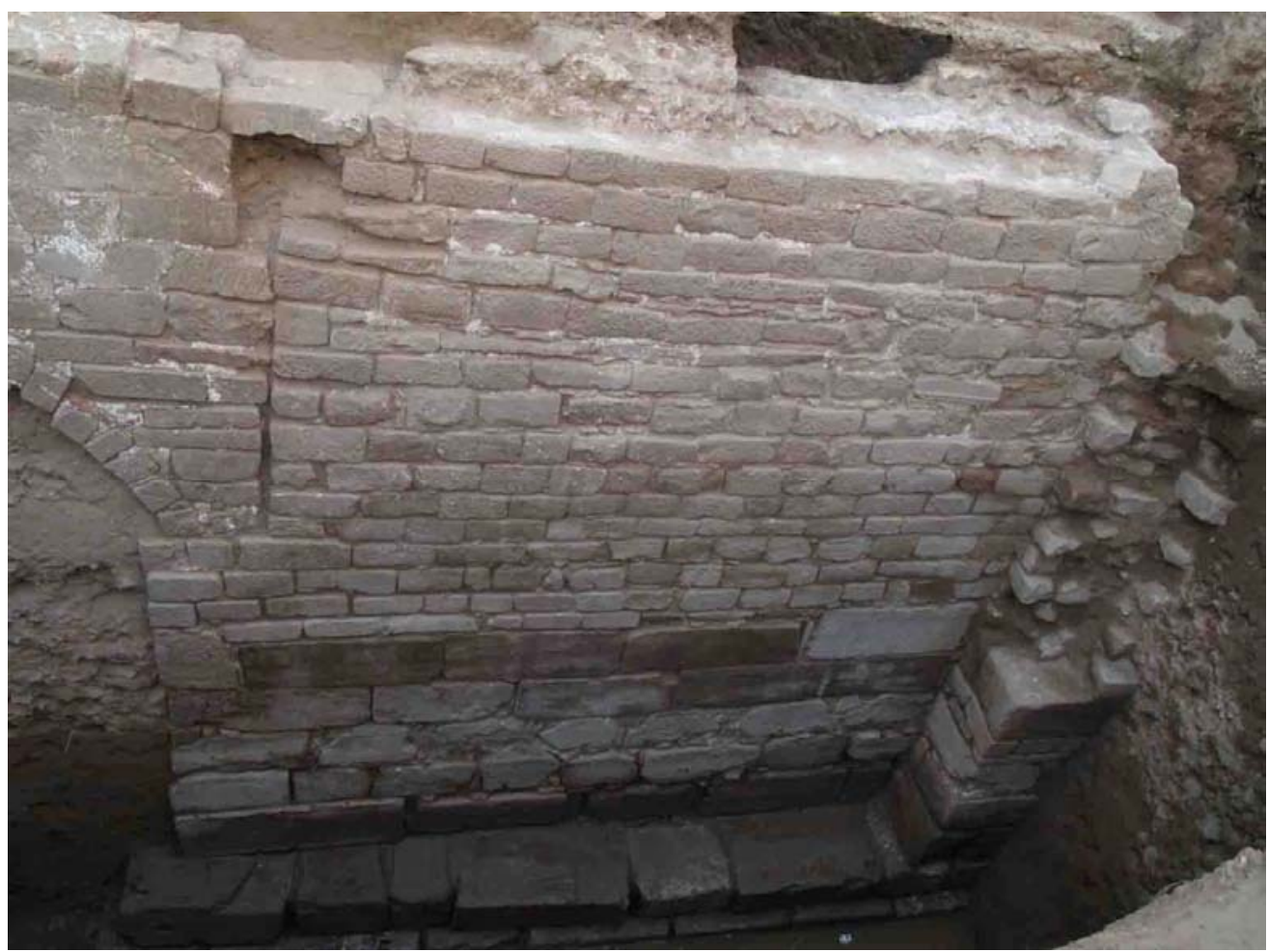

Fig. 29: Area 52: The northern part of the embankment wall. 


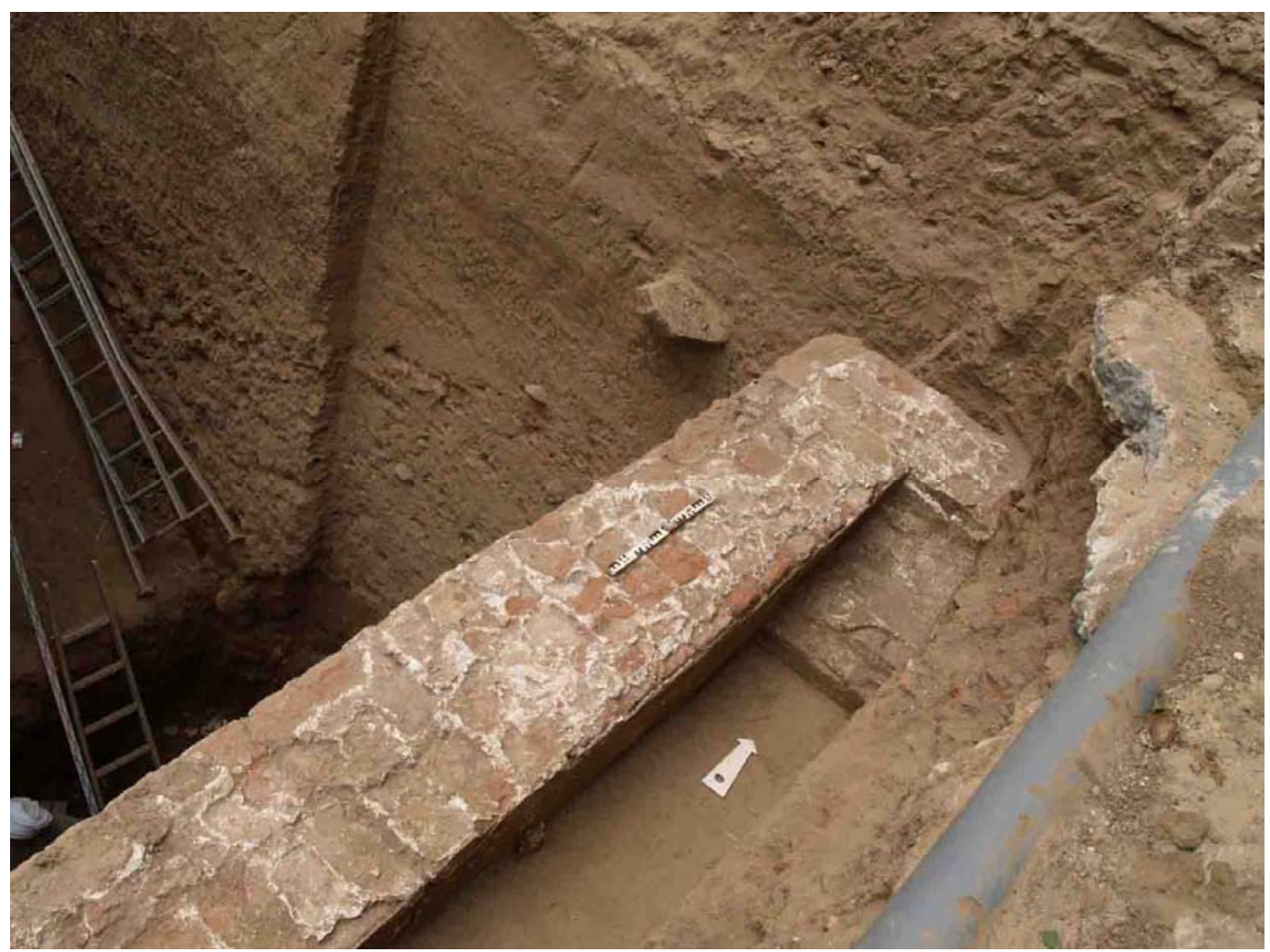

Fig. 30: Area 52: Top-view of the northern part of the embankment.

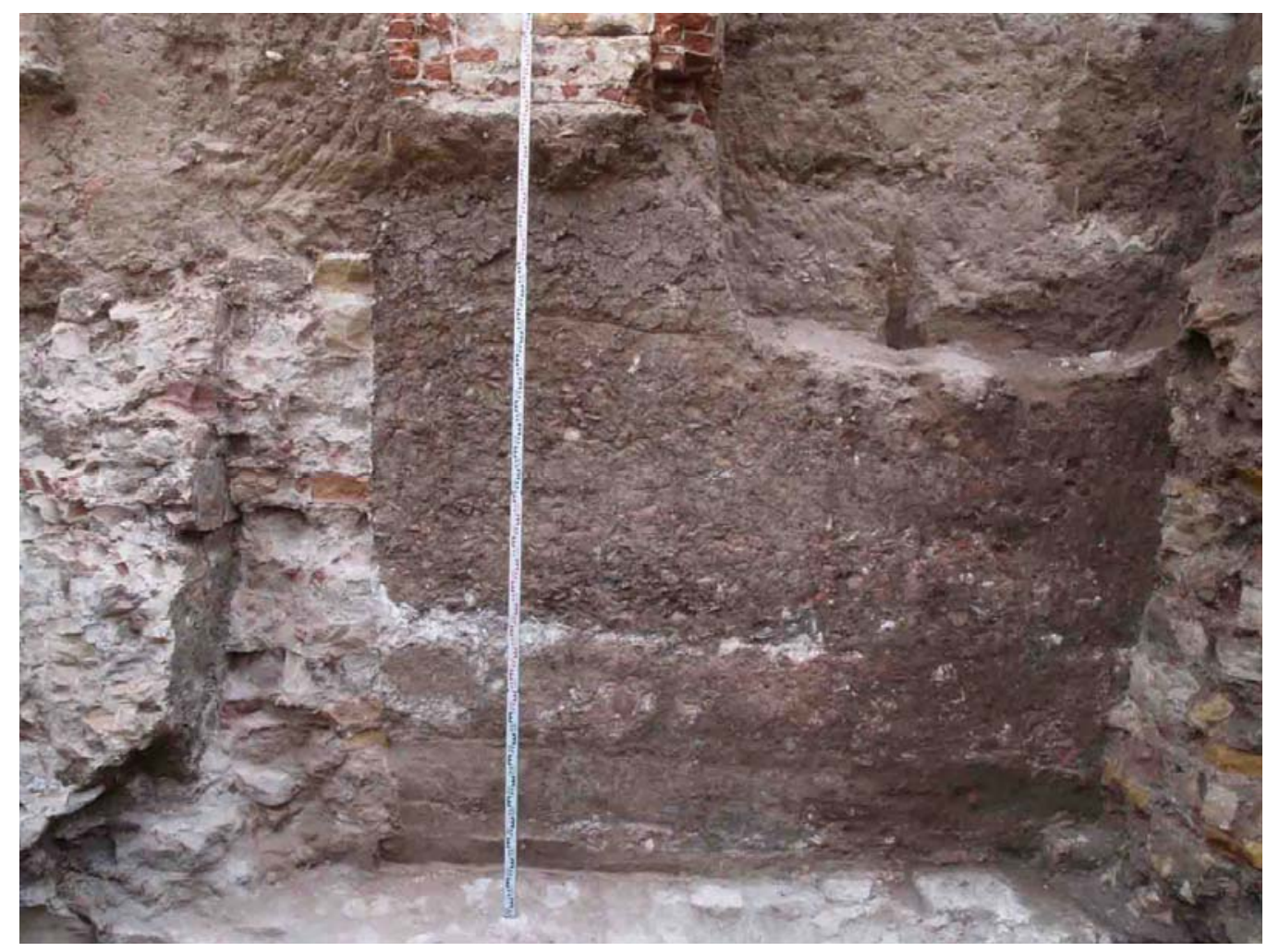

Fig. 31: Area 52: Detail of the eastern section with the northern basin. 


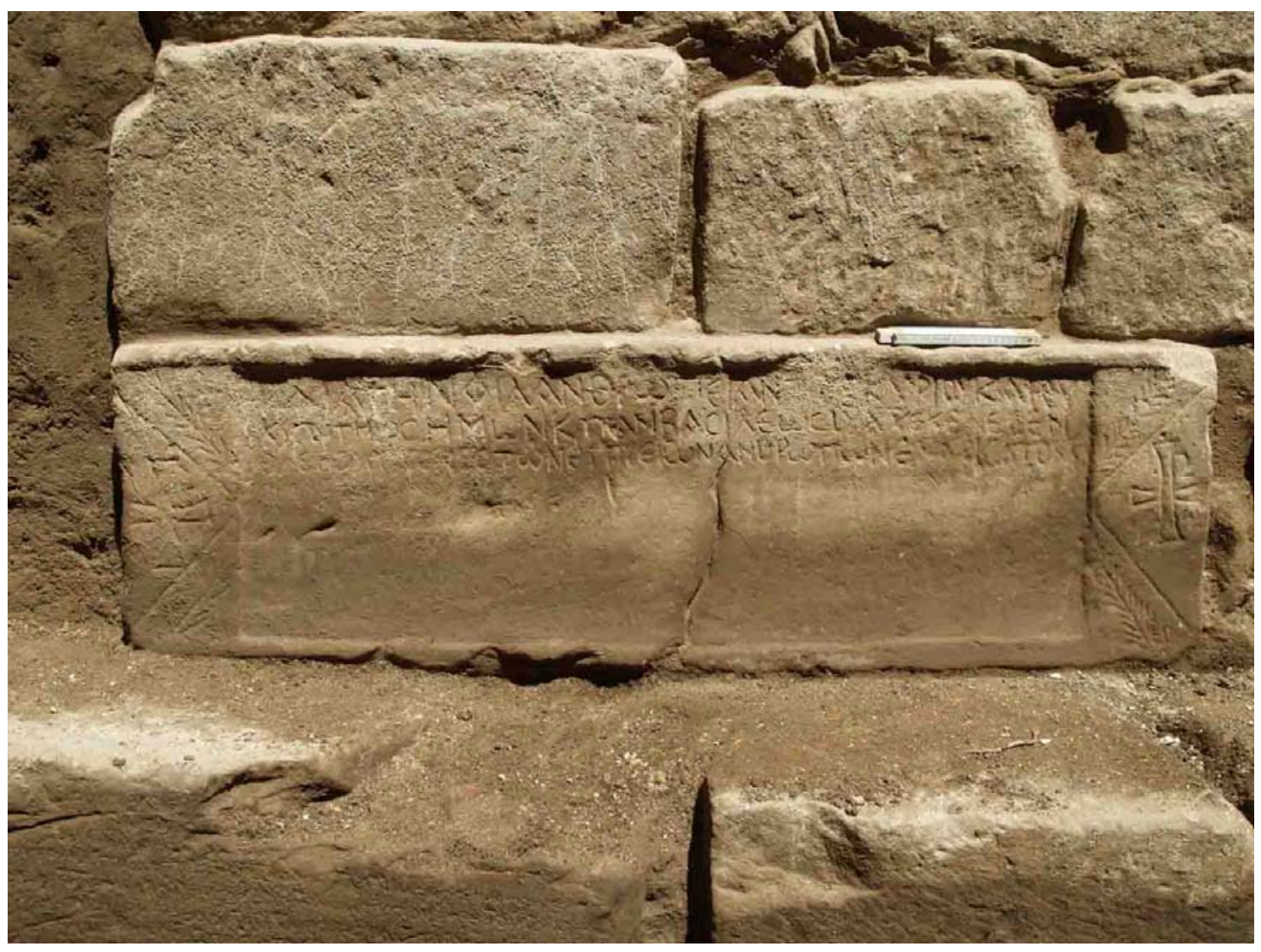

Fig. 32: Area 52: Reused block with Greek inscription.

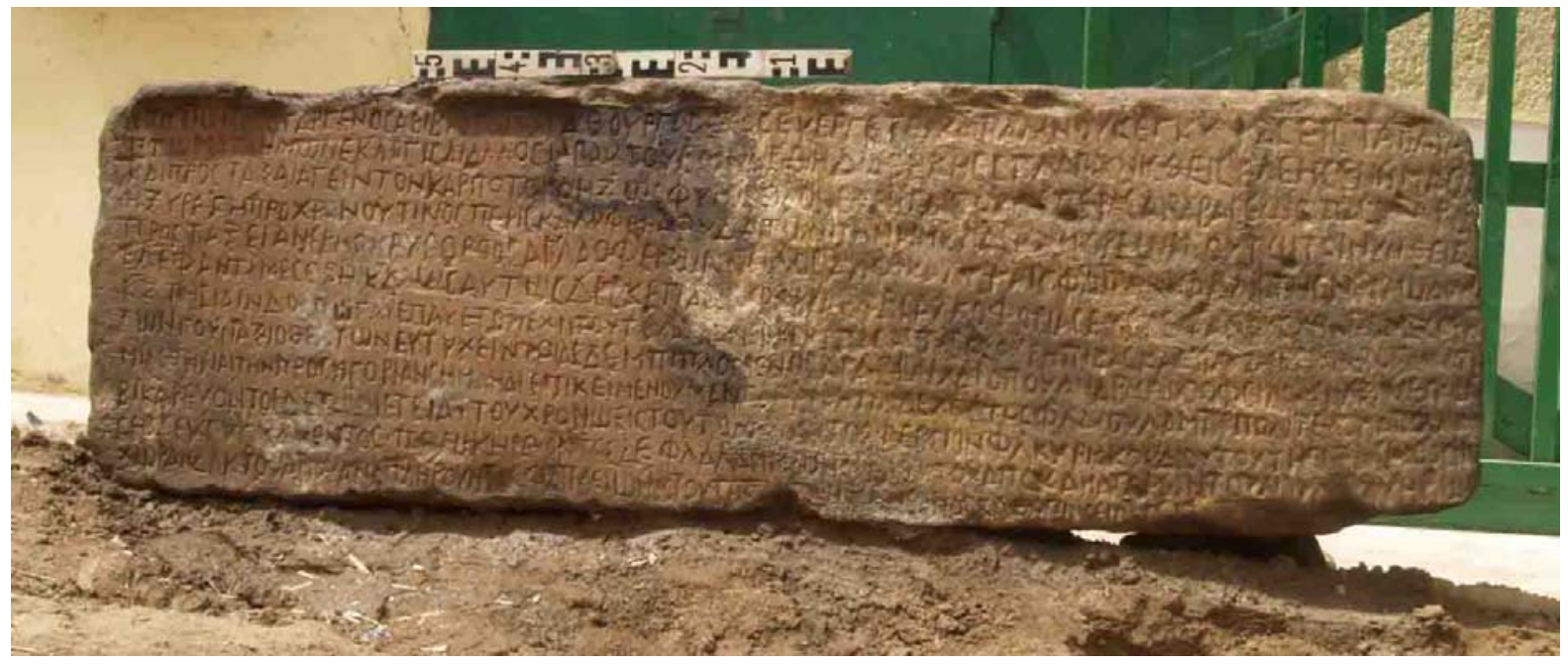

Fig. 33: Area 52: Greek inscription after recovery. 